\title{
The Development of Accounting Quality of IAS and IFRS Over Time: The Case of Germany ${ }^{1}$
}

April 2008, Revised July 2008.

\author{
Mari Paananen ${ }^{2}$ \\ Business School \\ University of Hertfordshire, \\ College Lane, Hatfield, AL10 9AB \\ United Kingdom \\ m.paananen@herts.ac.uk \\ Henghsiu Lin \\ University of Portland \\ Pamplin School of Business Administration \\ 5000 North Willamette Blvd. \\ Portland, OR 97203 \\ lin@up.edu
}

\footnotetext{
${ }^{1}$ We thank the anonymous reviewers of the Journal of International Accounting Research, Dr. Eva Jermakowicz, the participants at the AAA 2008 Semi-annual International Accounting Section meeting in San Diego, and the participants at workshops at Göteborg University, Keele University and Warwick University for helpful comments.

${ }^{2}$ Corresponding author
} 


\begin{abstract}
We examine the characteristics of accounting amounts using a sample of German companies reporting under IAS during 2000-2002 (IAS period), and IFRS during 2003-

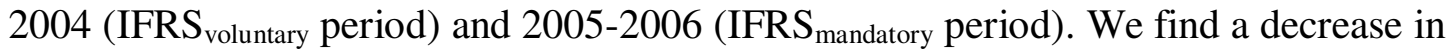
accounting quality after the mandatory EU adoption in 2005. Our findings on earnings smoothing and timely loss recognition corroborates largely our findings related to value relevance of accounting information. Our results indicate that accounting quality has not improved but worsened over time. Further analysis shows that this development is less likely be driven by new adopters of IFRS but is driven by the changes of the standards. Contrary to the intention with the adoption of the European adoption of IFRS, this makes it harder for investors to base their decisions on the IFRS financial reporting.
\end{abstract}




\section{Introduction}

The main objective of this study is to examine and compare the quality of accounting numbers under International Accounting Standards (IAS) during 2000-2002 with those under International Financial Reporting Standards (IFRS) during 2003-2006³. Accordingly, we compare the characteristics of accounting amounts using a sample of German companies reporting under IAS during 2000-2002 (IAS period), and IFRS during 2003-2004 (IFRS voluntary period) and 2005-2006 (IFRS $_{\text {mandatory }}$ period). Specifically, we investigate whether there is a change in accounting quality during these three time periods. We limit our investigation to German companies to hold constant certain institutional factors such as stock listing requirements, accounting disclosure requirements, market microstructures and regulatory environments that may confound the results, thereby strengthening the reliability of our findings.

Our inquiry is mainly motivated by the major revisions of IASs and the development of new IFRSs since the implementation of the new structure with IASB taking over the standard setting responsibilities from IASC in April 2001. The IASB has focused on developing a set of high quality standards to promote global accounting harmonization. This has led to significant changes in standards; only 31 of the 41 IASs remained in effect as of January 2005. In addition, by this time, IASB has issued eight new IFRSs (IASB). Many of these revisions and new additions of accounting standards reflect IASB's preference for fair value measurement of assets and liabilities (Alexander and Jermakowicz 2006; Hung and Subramanyam 2007; Schipper 2005; Whittington 2005). Considering the developments in the international standards, we predict that these

\footnotetext{
${ }^{3}$ Beginning in 2005, all listed companies in the European Union (EU) are required to prepare their consolidated financial statements in accordance with IFRS. Prior to that, using IAS/IFRS was voluntary in many European countries.
} 
changes are likely to affect the quality of accounting amounts as a result of IASB's increased orientation towards fair value accounting.

The European Union's (EU) adoption has made IFRS the most widely accepted financial accounting model in the world. It is very important that current and potential investors as well as the standard setters understand the implication of IFRS on accounting variables. Hence, we also examine the effect of the EU's mandatory adoption of IFRS in 2005 and 2006 on the quality of accounting. Specifically, we examine whether the mandatory adoption of IFRS in the EU may have changed the structure of the set of companies reporting under IFRS and how this may have impacted the overall accounting quality.

Prior research has compared properties of accounting numbers using samples of German companies (e.g., Hung and Subramanyam 2007; Bartov and Kim 2005; Barth et al. 2008, Barth et al. 2006). Our study differs from prior research on quality of IAS and IFRS accounting measures in that we examine the change in quality of accounting caused by the revisions made to IASs and the development of new IFRSs. This study compares the characteristics of accounting amounts using a sample of German companies reporting under IAS during 2000-2002, and IFRS during 2003-2004 and 2005-2006. Specifically, we investigate whether there is a change in accounting quality during these three time periods as IASB revises existing IAS and issues new IFRS to formulate a set of high quality international accounting standards for global financial reporting purpose.

Contrary to our expectations, our results suggest a decrease in accounting quality after the mandatory EU adoption of IFRS. We find that earnings and book value of equity are becoming less value relevant during the IFRS periods compared to the IAS period. Our 
findings on earnings smoothing and timely loss recognition largely corroborates our findings with respect to the value relevance of accounting information. Our results indicate that accounting quality has not improved but worsened over time. Further analysis shows that this is less likely to be driven by new adopters of IFRS in 2005 and more by the change in international accounting standards. When using a matched sample we cannot find any clear indication of either an improved or a worsened quality of financial reporting. We also analyzed the voluntary and the mandatory adopters in the period 2005 to 2006 . We found only weak indications that the decrease in quality was caused by the mandatory adopters. Furthermore, we also investigated whether our results were driven by a new dominating industry group, Financials. We find nothing supporting that this is the case and our interpretation is that the decrease in accounting quality is driven by the revisions of IASs and the addition of new of IFRSs around the time of the European mandatory adoption. Contrary to the intention with the European adoption of IFRS, this might make it harder for investors to base their decisions on the accounting information.

Our primary contribution is that we exclusively examine the impact of international standards over time on accounting quality and value relevance of accounting measures as these standards go through revisions and new standards are issued. No study, to our knowledge, has empirically examined this issue. Our second contribution is that we include more recent data and investigate the effects of the mandatory EU adoption of IFRS since 2005 on accounting quality.

The remainder of our paper is organized as follows. The next section describes the development of international accounting standards over time. Section III briefly 
discusses prior research and develops hypotheses. Section IV discusses the research design and how we examine earnings smoothing, timely loss recognition and value relevance over time. Section V describes the sample, and the sample selection criteria. Section VI presents our findings while Section VII concludes.

\section{The Development of International Accounting Standards over Time}

During the period of our investigation, a number of revisions to International Accounting Standards took place. These changes are summarized in Table 1, which outlines the revisions of existing IASs and the issuance of new IFRSs in the chronological order these changes went into effect. Of these changes, we consider three to have had a major impact on companies' financial reporting and thereby the possibility of a major impact on the value relevance on book value of equity and earnings. Theses changes are related to IAS 36, Impairment of assets, IAS 38, Intangible assets, and IFRS 3, Business combinations. IAS 36 requires a review of assets including intangible assets with an indefinite useful life for impairment, and measurement of recoverable amounts on an annual basis. Any impairment loss is recorded as an expense in the income statement. IAS 38 requires the recognition of an intangible asset when it is probable that future benefits of an intangible asset will benefit the company, and the cost of the intangible asset can be measured reliably. In addition, intangible assets should also be assessed for impairment in accordance with IAS 36. IFRS 3 allows only the purchase method for business combinations. All identifiable assets and liabilities are valued at fair value. Goodwill is not amortized, but subject to an impairment test annually. Negative goodwill is recognized immediately in the income statement. Since the changes in these 
accounting standards are all fair-value oriented, we expect the informativeness of IFRS earnings and book values to increase compared to that of IAS earnings and book values.

\section{<Table 1 about here $>$}

\section{Prior Research and Hypotheses Development}

As noted earlier, some recent studies compare IAS accounting measures to those under other GAAPs. Hung and Subramanyam (2007) compare the financial statement effects of using IAS to those using German GAAP for a sample of German companies that elected to adopt IAS by examining these companies' restatements of prior years accounting numbers in the adoption year. They find that the adjustments between the two reporting systems are value relevant for book values of equity, but not for earnings. But they do not find any difference in value relevance of book value of equity and earnings under IAS and German GAAP. They also find that total assets and book value of equity are significantly higher under IAS and that there is a higher variability in book value of equity and earnings under IAS. Finally, they find that IAS adopters exhibit larger loss provisions. Bartov et al. (2005) also examine and compare the value relevance of earnings based US GAAP, IAS and German GAAP. They, on the other hand, find that IAS earnings are more value relevant than those based on German GAAP. The difference in the results of these two studies may be found in that Bartov et al. (2005) exclude loss-firm observations in their estimations while these are included in the Hung Subramanyam (2007) study.

Jermakowicz et al. (2007) examine German companies' adoption of IFRS and US GAAP over the period 1995 to 2004. Specifically, they investigate the usefulness, proxied as value relevance, before and after the adoption of these GAAPs and the 
perceived benefits and costs related to the process of implementing IFRS among the DAX-30 companies. ${ }^{4}$ They find a significant increase in the value relevance of earnings after the adoption of these GAAPs. They also find that the key challenges related to the adoption of IFRS are the complexity of IFRS, the costs involved, and the lack of implementation guidance. The challenges related to the adoption of IFRS documented by Jermakowicz et al. (2007) and Soderstrom and Sun (2007) may explain the findings of Christensen et al. (2007). Christensen et al. (2007) investigate the change in earnings management and timely loss recognition among German firms that voluntarily adopt IFRS and those who wait until the adoption of IFRS is mandatory. They find that companies that voluntarily adopt are less prone to earnings management and recognize losses more timely compared to those that resist and wait until the adoption of IFRS becomes mandatory. They interpret their findings as a sign of how certain companies (i.e. insider oriented companies) have less incentive to adopt IFRS since they will not benefit and the challenges involved are considerable.

Finally, Barth et al. (2008) also study IAS adopters from a number of countries, whereof Germany is one of the countries with greatest representation in the sample. They find that firms that adopt IAS are less prone to engage in earnings smoothing and recognize losses more timely.

There are also other recent studies on the effect of German and other GAAPs' on accounting quality and cost of capital. Leuz and Verrecchia (2000) investigate the bidask spreads, trading volume, and stock return volatility as proxies for the information asymmetry part of cost of capital. Comparing the above proxies for German companies

\footnotetext{
${ }^{4}$ DAX-30 (Deutscher Aktien IndeX 30 (formerly Deutscher Aktien-Index-30) is a Blue Chip stock market index consisting of the 30 major German companies trading on the Frankfurt Stock Exchange.
} 
which switch from German GAAP to either IAS or US GAAP, as they predict, they find that the bid-asked spread decreases, and the trading volume increases, however they find no reduction in stock return volatility. Daske (2006) builds on Leuz and Verrecchia's (2000) study using data from 1993 and 2002. He, on the other hand, does not find any sign of a lower cost of capital for companies that switch to IAS or US GAAP. On the contrary, Daske (2006) finds an increase in cost of capital for these companies. Finally, Platikanova and Nobes (2006) compare the information asymmetry component of the bid-ask spread among companies before and after EU's adoption of IFRS in 2005. They find a larger volatility in the information asymmetry for UK and German companies. Contrary to expectations, they also find that companies from countries where earnings management is more common exhibit a lower information asymmetry component compared to other groups of countries. They interpret this result as income smoothing reduces information asymmetry.

Overall, the results of these studies do not provide clear evidence on how the recent development in the global accounting standards impacts the quality of the accounting amounts. For instance, Barth et al. (2008) and Jermakowicz et al. (2007) cover a period including both IAS and IFRS data, which makes it difficult to interpret their results regarding the impact on accounting quality as the international accounting standards go through changes over time. In addition, the fact that Bartov et al. (2005) exclude loss-firm observations and obtain a result different from Hung and Subramanyam (2005) suggests that certain characteristics of the companies reporting under international accounting standards may drive the results. This notion is supported by the findings of both Jermakowicz et al. (2007) and Christensen et al. (2007). Jermakowicz et al. (2007) 
results suggests that the value relevance of earnings increases after companies adopt IFRS or US GAAP, a notion that make sense considering the sample used in the study (DAX-30 companies), a set of companies that are most likely to be able to cope with the complexity of implementing these GAAPs. They also find that, in spite of these companies' ability to cope with an adoption to a more complex GAAP, they still find the adoption of IFRS to be a major challenge due to its complexity, high cost, and the lack of implementation guidance. Christensen et al.'s (2007) results suggests that companies that have an incentive to implement a more challenging GAAP are more likely to maintain a higher accounting quality (proxied as earnings management and timely loss recognition) compared to those who do not.

We assume that the recent developments in the international accounting standards have led to changes in the quality of financial reporting over time. Therefore, the question remains whether the accounting quality is higher as a result of the IASB's initiatives and actions. As the IASB reduces the allowable alternative accounting methods and choices and provides a more consistent approach to accounting measurement for the goal of developing a single set of high quality international accounting standards, we predict that these changes in recent years improve the quality of accounting as evidenced by higher value relevance of earnings and book value of equity, less earnings smoothing, and more timely recognition of losses.

With respect to value relevance, we expect to see higher association between stock prices and earnings and book value of equity for firms with higher quality of reported accounting numbers. Moreover, we expect that firms with less earnings smoothing will exhibit more variability in change in net income, a higher ratio of the 
variability of change in net income to variability of change in cash flow, a less negative correlation between accruals and cash flows and less frequency of reporting small positive earnings as the accounting quality improves. With respect to timely loss recognition, we predict that firms with higher accounting quality show a larger frequency of large losses.

\section{Research Design}

We follow Barth et al. (2008) and Lang et al. 2005) when testing our predictions of higher quality of accounting as the IASB revises IAS and issues new IFRS in the recent years, we divide our study period (2000-2006) to three time periods: the IAS period ranging from 2000-2002; the IFRS voluntary period ranging from 2003-2004 and the IFRS $_{\text {mandatory }}$ period ranging from 2005-2006. Following prior research, we operationalize quality of accounting using earnings smoothing, timely recognition of losses measures, and value relevance.

Four measures of earnings smoothing are used in this study. They are the variability of the change in net income, the ratio of the variability of the change in net income to the variability of the change in operating cash flows, the correlation between accruals and cash flows and the frequency of small positive net income (Lang et al. 2005; Barth et al. 2006, 2008). Our first earnings smoothing metric is the variability of the change in net income scaled by total assets, $\Delta$ NI (Barth et al. 2006, 2008; Lang et al. 2006). To control for other economic factors that affect earnings variability unrelated to

the financial reporting system, we regress $\Delta \mathrm{NI}$ on a number of control variables identified in prior literature (Ashbaugh 2001; Pagano et al., 2002; Lang et al., 2003; Tarca 2004; 
Lang et al. 2006; Barth et al., 2006, 2008), and the variances of the residuals of the regression is our measure of the earnings variability. The $\Delta \mathrm{NI}$ is estimated as follows:

$$
\begin{aligned}
& \Delta N I_{i t}=\beta_{0}+\beta_{1} L_{E V 1_{i t}}+\beta_{2} \text { Growth }_{i t}+\beta_{3} \text { Eissue }_{i t}+\beta_{4} \text { Dissue }_{i t}+\beta_{5} \text { Turn }_{i t}+\beta_{6} \text { Size }_{i t}+ \\
& \beta_{7} \text { CFO }_{i t}+\beta_{8} A U D_{i t}+\beta_{9} \text { NUMEX }_{i t}+\beta_{10} \text { XLIST }_{i t}+\beta_{11} F F_{i t}+\varepsilon_{i t .}
\end{aligned}
$$

where:

$L E V=$ the total liabilities divided by shareholders' equity;

GROWTH $=$ the percentage of change in sales;

Eissue $=$ the percentage change in common shareholders' equity;

Dissue $=$ the percentage change in total liabilities;

Turn $=$ sales divided by total assets;

Size $=$ the natural $\log$ of total assets;

$C F O=$ the cash flow from operating activities scaled by total assets

$A U D=$ a dummy variable taking the value one if the firm's auditor is PwC, KPMG, Arthur Andersen, E\&Y, or D\&T and zero otherwise;

$N U M E X=$ the number of stock exchanges on which a firm's stock is listed;

$X L I S T=$ a dummy variable taking the value one if the firm is listed on a U.S. stock

exchange (the U.S. not being the primary exchange) and zero otherwise.

$F F=$ the average number of shares traded the last day of the month during the fiscal year divided by number of common shares outstanding at the fiscal year end.

We estimate equation (1) pooling observations in each of the three time periods examined and compare the variances of the residuals of the regression for each time period using a two-tailed variance ratio F-test.

Our second measure of earnings smoothing is the ratio of the variability of the change in net income, $\Delta \mathrm{NI}$, to the variability of the change in operating cash flows, 
$\triangle \mathrm{CFO}$ (Barth et al., 2006; Lang et al., 2006). $\triangle \mathrm{CFO}$ is the change in cash flows scaled by total assets. As with $\Delta \mathrm{NI}$, to control for other economic factors that affect cash flows variability unrelated to financial reporting system, we regress $\triangle \mathrm{CFO}$ on a number of control variables similar to equation (1), but with $\triangle \mathrm{CFO}$ as the dependent variable.

$\Delta C F O_{i t}=\beta_{0}+\beta_{1} L_{E V 1} 1_{i t}+\beta_{2}$ Growth $_{i t}+\beta_{3}$ Eissue $_{i t}+\beta_{4}$ Dissue $_{i t}+\beta_{5}$ Turn $_{i t}+\beta_{6}$ Size $_{i t}+$ (2), $\beta_{7} C F O_{i t}+\beta_{8} A U D_{i t}+\beta_{9} N U M E X_{i t}+\beta_{10} X L I S T_{i t}+\beta_{11} F F_{i t}+\varepsilon_{i t}$

The variability of the change in cash flows is the variance of residuals from equation (2). Then the second measure of earnings smoothing is the ratio of the variability of $\Delta \mathrm{NI}$ to the variability of $\triangle \mathrm{CFO}$. The rationale for using this ratio is that it is plausible that the variability of net income is affected by the firm-specific volatility of cash flows and by using the ratio we control for this (Barth et al. 2006, 2008; Lang et al. 2006). We measure the difference between these ratios across time periods using ranksum test of the permuted dataset.

The third measure of earnings smoothing is the spearman correlation between accruals and cash flows. As with the previous tests, to control for economic factors unrelated to earnings smoothing, we run separate regressions of accruals and cash flows on the control variables as included in Equations 1 and 2, except $C F O$.

$$
\begin{aligned}
& C F O_{i t}=\beta_{0}+\beta_{1} L E V 1_{i t}+\beta_{2} \text { Growth }_{i t}+\beta_{3} \text { Eissue }_{i t}+\beta_{4} \text { Dissue }_{i t}+\beta_{5} \text { Turn }_{i t}+\beta_{6} \text { Size }_{i t}+ \\
& \beta_{7} \text { AUD }_{i t}+\beta_{8} N U M E X_{i t}+\beta_{9} \text { XLIST }_{i t}+\beta_{10} F F_{i t}+\varepsilon_{i t .} \\
& \text { ACC }_{i t}=\beta_{0}+\beta_{1} \text { LEV }_{i t}+\beta_{2} \text { Growth }_{i t}+\beta_{3} \text { Eissue }_{i t}+\beta_{4} \text { Dissue }_{i t}+\beta_{5} \text { Turn }_{i t}+\beta_{6} \text { Size }_{i t}+ \\
& \beta_{7} \text { AUD }_{i t}+\beta_{8} N U M E X_{i t}+\beta_{9} \text { XLIST }_{i t}+\beta_{10} \text { FF }_{i t}+\varepsilon_{i t .} .
\end{aligned}
$$

We then compare and test the correlation of the residuals from equations (3) and (4) between the three time periods based on Cramer's (1987) squared correlation test. 
To test managing towards positive earnings, we run the following model including two periods (IAS vs. IFRS voluntary $_{\text {and }}$ IFRS $_{\text {voluntary }}$ vs. IFRS mandatory $_{\text {) at a time to }}$ examine if firms in one period are more likely to manage towards positive earnings (Barth et al., 2006; Lang et al., 2006) than the other. The coefficient on the small positive net income is our measure of managing towards positive earnings.

$$
\begin{aligned}
& \text { IAS }(0,1)_{i t}=\beta_{0}+\beta_{1} S P O_{i t}+\beta_{2} L E V_{i t}+\beta_{3} \text { Growth }_{i t}+\beta_{4} \text { Eissue }_{i t}+\beta_{5} \text { Dissue }_{i t}+ \\
& \beta_{6} \text { Turn }_{i t}+\beta_{7} \text { Size }_{i t}+\beta_{8} C F O_{i t}+\beta_{9} A U D_{i t}+\beta_{10} N U M E X_{i t}+\beta_{11} X_{L I S T}+ \\
& \beta_{12} F_{i t}+\varepsilon_{i t .}
\end{aligned}
$$

and

$$
\begin{aligned}
& \left.\operatorname{IFRS}_{(0,1)}\right)_{i t}=\beta_{0}+\beta_{1} \text { SPO }_{i t}+\beta_{2} L E V_{i t}+\beta_{3} \text { Growth }_{i t}+\beta_{4} \text { Eissue }_{i t}+\beta_{5} \text { Dissue }_{i t}+ \\
& \beta_{6} \text { Turn }_{i t}+\beta_{7} \text { Size }_{i t}+\beta_{8} \text { CFO }_{i t}+\beta_{9} \text { AUD }_{i t}+\beta_{10} \text { NUMEX }_{i t}+\beta_{11} \text { XLIST }_{i t}+ \\
& \beta_{12} F_{i t}+\varepsilon_{i t .}
\end{aligned}
$$

$\operatorname{IAS}(0,1)$ in the first estimation is equal to 1 for the IAS period and zero for the IFRS $_{\text {voluntary }}$ period and in the second estimation, the $\operatorname{IAS}(0,1)$ is equal to 1 for the IFRS $_{\text {voluntary }}$ and zero for the IFRS $S_{\text {mandatory }}$ period. SPO is a binary variable equal to 1 if net income scaled by total assets is between 0 and 0.01 (Barth et al., 2006; Lang et al., 2006; Lang et al., 2003). A positive coefficient on SPO in the estimation covering the IAS (IFRS voluntary $)$ period and the $\operatorname{IFRS}_{\text {voluntary }}\left(\operatorname{IFRS}_{\text {mandatory }}\right)$ period indicates that firms in

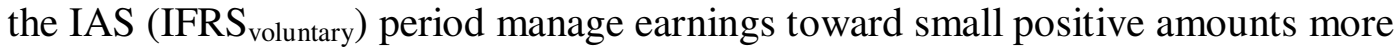
frequently than firms in the $\operatorname{IFRS}_{\text {voluntary }}\left(\operatorname{IFRS}_{\text {mandatory }}\right.$ period.

For the measure of timely recognition of losses, we also estimate an equation similar to equation (5) and (6), but replacing SPO with LNEG.

$$
\begin{aligned}
& \operatorname{IAS}(0,1)_{i t}=\beta_{0}+\beta_{1} L N E G_{i t}+\beta_{2} L E V_{i t}+\beta_{3} \text { Growth }_{i t}+\beta_{4} \text { Eissue }_{i t}+\beta_{5} \text { Dissue }_{i t}+ \\
& \beta_{6} \text { Turn }_{i t}+\beta_{7} \text { Size }_{i t}+\beta_{8} \text { CFO }_{i t}+\beta_{9} A U D_{i t}+\beta_{10} N U M E X_{i t}+\beta_{11} X_{L I S T}+ \\
& \beta_{12} F F_{i t}+\varepsilon_{i t}
\end{aligned}
$$


and

$\operatorname{IFRS}(0,1)_{i t}=\beta_{0}+\beta_{1} L_{N E G}+\beta_{2} L_{E V} V_{i t}+\beta_{3}$ Growth $_{i t}+\beta_{4}$ Eissue $_{i t}+\beta_{5}$ Dissue $_{i t}+$

$\beta_{6}$ Turn $_{i t}+\beta_{7}$ Size $_{i t}+\beta_{8}$ CFO $_{i t}+\beta_{9} A U D_{i t}+\beta_{10} N U M E X_{i t}+\beta_{11} X L I S T_{i t}+$ $\beta_{12} F F_{i t}+\varepsilon_{i t}$

LNEG is a binary variable taking on the value of 1 for observations with annual earnings scaled by total assets less than negative 0.2 , and zero otherwise. The coefficient on LNEG is our measure of timely loss recognition. A positive coefficient on LNEG

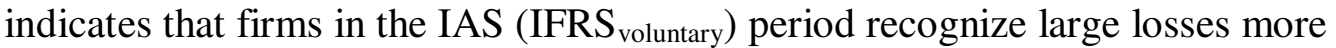

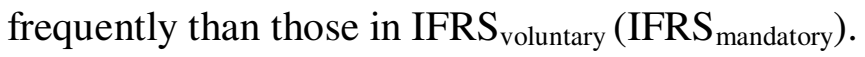

In addition, we also use Basu's (1997) reverse regressions of earnings on a dummy variable for bad news (negative returns), annual return, and an interaction variable of return and the dummy variable for bad news. We expect that more timely loss recognition will result in a larger coefficient on bad news earnings. We compare the magnitude of the interaction coefficient across the three periods to evaluate the timeliness of bad news reflected in earnings. A larger coefficient indicates more timely loss recognition.

The test of relative value relevance is based on a valuation framework provided by Ohlson (1995) where a firm's share price is a function of both earnings and book value of equity.

$$
P_{i t}=\beta_{0}+\beta_{1} E_{i t}+\beta_{2} B V E+\varepsilon_{i t}
$$

where $\mathrm{P}_{\mathrm{it}}$ is the market price per share three months after fiscal year end in year $t$ of company ${ }_{i}$, and $\mathrm{E}_{i t}$, and $\mathrm{BVE}_{i t}$ are earnings before extraordinary items, and book value of stockholders' equity per share, respectively, and $\varepsilon_{\text {it }}$ is the other value-relevant information 
of company $i$ in year $t$. The regression model's $\mathrm{R}^{2}$ indicates the strength of the association between the respective accounting variable(s) and stock price.

We also use a reverse regression with earnings as the dependent variable and returns as the independent variable. We expect that if losses are recognized in a timely manner, the association between returns and earnings is stronger, mirroring that more information about earnings reaches the equity market on in the period the loss occurs and not later (Basu 1997). Hence, we predict an increase in the association between earnings and return over the three time periods under investigation.

\section{Sample Selection and Descriptive Statistics}

The initial sample consists of all industrial German listed companies found in the Datastream database in the years 2000 - 2002, 2003 - 2004 and 2005-2006, indicating IAS/IFRS as their primary accounting standards. ${ }^{5}$ German companies often are traded on more than one domestic stock exchange; we choose the common stock issue of the highest market value as the company's primary stock issue, and use the stock price of that issue when a company has multiple issues of common stocks. For the value relevance test, the sample selection process yields a German IAS sample of 187 firm-year observations for 107 companies, a German IFRS voluntary sample of 204 firm-year observations and companies, and a German IFRS $S_{\text {mandatory }}$ sample of 448 firm-year observations and companies. Table 2 outlines our sample selection procedures for the value relevance tests.

In addition, to mitigate the effect of different firms in each period on the regression estimations, we match the sample firms in one period with the same firms in

\footnotetext{
${ }^{5}$ We include all firms where the applied accounting standards are either international accounting standards or IFRS.
} 
the next period, and re-run all equations with the matched sample. This procedure yields 159 observations (92 companies) under the IAS period, 92 observations (92 companies) for the IFRS voluntary $_{\text {period, and } 90 \text { observations (90 companies) under the IFRS }}$ mandatory period.

\section{$<$ Table 2 about here $>$}

As shown in Table 3 below, the Electronic industry is the largest industry cluster

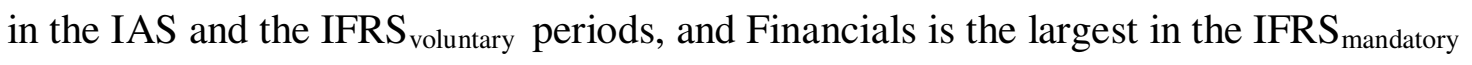
period. The Financials industry is the second largest industry during the IAS period, and the Financials and Machinery and Equipment firms are both the second largest industries during the IFRS voluntary $_{\text {period and Financials during the IFRS }}$ mandatory period. One of the most notable change in industry specialization is an increase in number of Financial firms in the IFRS $S_{\text {mandatory }}$ period. It seems that most of the Financials firms were not using the IAS/IFRS until the mandatory adoption of IFRS in 2005. Another change is the steady relative decrease of firms within the Recreation industry.

\section{<Table 3 about here>}

Table 4 presents the descriptive statistics of earnings smoothing, timely loss recognition metrics, and value relevance, followed by the control variables. ${ }^{6}$ The earnings per share (EPS) increases significantly across the periods, which is plausible considering the economic upturn between 2003 and 2006. There is a significant increase in book value of shareholders' equity per share (BVPS) between the IFRS voluntary $_{\text {period and the }}$ IFRS $_{\text {mandatory }}$ period. The change in net income $(\Delta \mathrm{NI})$ increases significantly from the IAS period to the IFRS $S_{\text {voluntary }}$ periods. The $\Delta \mathrm{NI}$ then decreases between the IFRS $\mathrm{voluntary}_{\text {period }}$

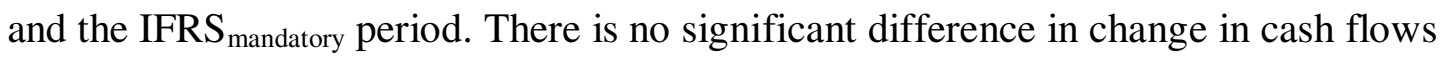

\footnotetext{
${ }^{6}$ Variables in all our analyzes are winsorized at the $1^{\text {st }}$ and $99^{\text {th }}$ percentiles to control for outliers.
} 


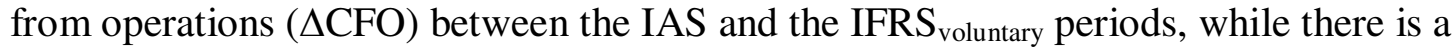
significant decrease between the the IFRS $S_{\text {voluntary }}$ and the IFRS $S_{\text {mandatory }}$ periods. There is a significant increase in accruals (ACC), measured as net income minus cash flow from operations scaled by total assets, between the IFRS voluntary $_{\text {and the }}$ IFRS $_{\text {mandatory }}$ periods, which could possibly be related to a buildup of accruals caused by the abolishment of amortization of acquired goodwill. There is no significant difference in the prevalence of reporting of small positive earnings (SPOS) across the three periods. There is a significant decrease in the reporting of large negative earnings (Lneg) across the IAS and the IFRS $_{\text {voluntary }}$ periods. This could be a sign of an increase in income smoothing behavior; however, this development could also be driven by the economic situation during the IAS period and the ongoing upturn during the two following period. The descriptive statistics on the control variables suggests that there is a decrease in growth

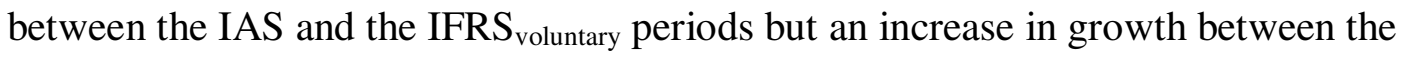

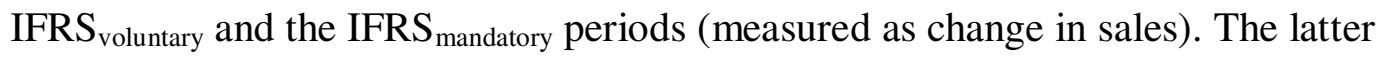
increase could be related to the new companies adopting IFRS in 2005. There is no statistically significant difference in change in common stock over the three periods. There is no significant difference in changes in total liabilities (Dissue) between the IAS

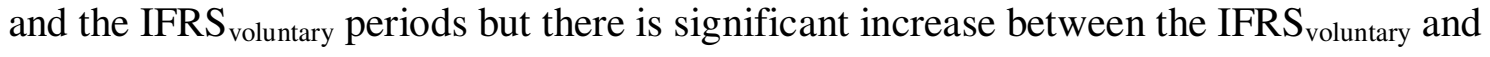
the IFRS mandatory $_{\text {periods. The significant increase in the IFRS }}$ mandatory period could be driven by the fact that many more companies now must adopt IFRS and this result in the inclusion of companies that are less capital market oriented and more reliant on debt in

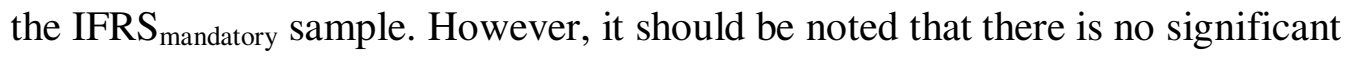
difference in leverage (measured as total liabilities to total shareholders' equity) across 
the three periods. There is a statistically significant increase in the asset turnover rate

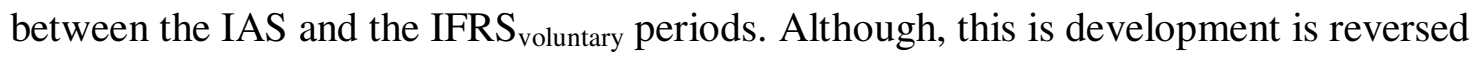

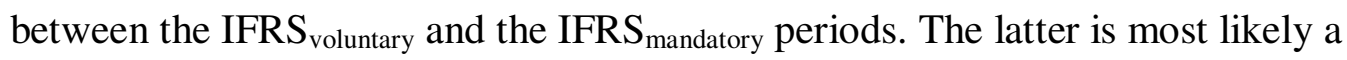
consequence of the inclusion of a large number of new IFRS adopters in the sample group. The size of the sample companies (measured as the natural log of total assets) decreases significantly between the IAS period and the IFRS $S_{\text {voluntary }}$ period. This could be driven by a lot of write downs during the IAS period due to the economic situation at that time, which is corroborated by the fact that in this period there was a significantly higher prevalence of reporting of large negative earnings. Finally, the cash flow from operations

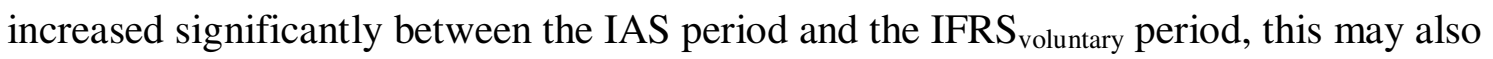
be explained by the improved economic conditions in the following periods. However, the cash flow from operations decreased significantly between the IFRS $\mathrm{voluntary}_{\text {and the }}$ IFRS $_{\text {mandatory }}$ periods, which could be related to the inclusion of a large number of new IFRS adopters in the sample group. Finally, there is a significant decrease in the free float between the IAS period and the IFRS voluntary $_{\text {period. }}$

\section{<Table 4 about here>}

\section{Results}

\section{Earnings Smoothing}

As reported in Table 5, Panel A, the results of the tests of earnings smoothing are contrary to our expectations in some instances. The variability in the change in net income, $\Delta \mathrm{NI}^{*}$, does increase significantly between the IAS and the IFRS $\mathrm{voluntary}_{\text {periods, }}$ however, there is a significant decrease between the IFRS $S_{\text {voluntary }}$ and the IFRS $\mathrm{S}_{\text {mandatory }}$ periods, suggesting an increase in income smoothing behavior. We also control for the 
firm-specific volatility in cash flow from operations by using the ratio of income variability and cash flow from operations variability. As predicted, the variability

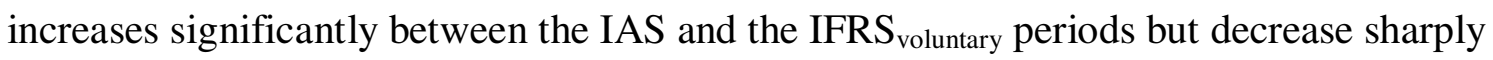

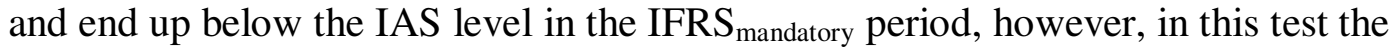
difference is statistically significant on the $5 \%$ level. Once again, this suggests an increase in income smoothing behavior. The correlation between the residuals from the regression on accruals (ACC) and cash flow from operations CFO shows an increase in the magnitude of the negative correlation indicating a significant increase in earnings management across the three periods. It should be noted that the correlation between $\mathrm{ACC}$ and $\mathrm{CFO}$ is positive in the IAS period. We interpret this as a sign that companies are growing and the growth is driving both an increase in CFO and a buildup of accruals. This notion is also confirmed by the measure of growth that was significantly larger in this period compared to the later two. Finally, there is no significant difference between the small positive income variable (SPOS) across the three periods.

\section{Timely Loss Recognition Tests}

Table 5, Panel B shows a significant decrease in the reporting of large negative earnings. As previously pointed out, the change in reporting of large negative earnings may be the result of an improvement of the economic conditions since the IAS period. However, most of our tests support the notion that the quality of accounting has decreased among German companies reporting under IAS and IFRS over time. Furthermore, the coefficient of the interaction variable of return and bad news shows a significant increase between the IAS period and the IFRS However, there is a significant decrease between the IFRS $S_{\text {voluntary }}$ period and the 
IFRS $_{\text {mandatory }}$ period indicating less timely loss recognition. This also may have something to do with the number of new adopters in the IFRSmandatory period.

\section{Value Relevance Test}

We measure value relevance in terms of the ability of accounting measures to explain stock prices. As shown in Table 5, Panel C, the overall $\mathrm{R}^{2}$ of the regression models for each of the time period examined was 0.44 in the IAS period, 0.09 in the

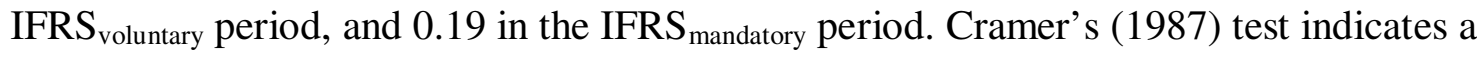
significant difference in $\mathrm{R}^{2}$ between all three periods. Contrary to our expectations, the $\mathrm{R}^{2} \mathrm{~s}$ of both the IFRS periods are lower than the $\mathrm{R}^{2}$ of the IAS period, indicating a lower usefulness of financial reporting under IFRS compared to IAS.

We also measure the $\mathrm{R}^{2}$ of a reverse regression where earnings is dependent variable and returns as the independent variable (Basu 1997). As predicted, there seem to be an increase in the association between earnings and returns between the IAS and the IFRS $_{\text {voluntary }}$ periods (from 0.19 to 0.28 ). However, this development is once again reversed between the IFRS voluntary $_{\text {and the IFRS }}$ mandatory periods (from 0.28 to 0.16 ). However, only the increase between the the IAS and the IFRS voluntary $_{\text {periods is }}$ statistically significant. Turning to the bad news observations only, once again, we find an expected increase in the association between the IAS and the IFRS voluntary $_{\text {period. }}$ However, contrary to expectations, this turns into a significant decrease from 0.35 to 0.11

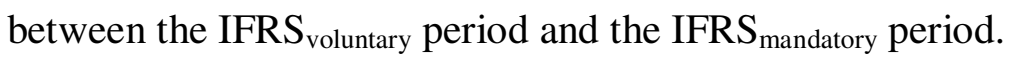

\section{<Table 5 about here>}


In summary, our tests show consistent evidence that the quality of accounting

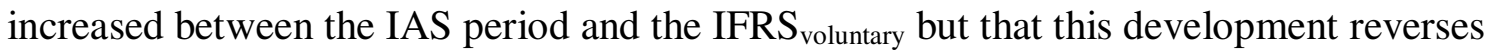

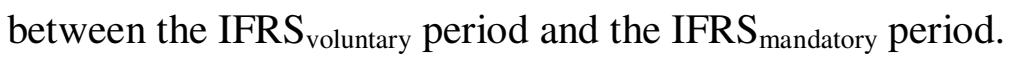

\section{Sensitivity Analysis}

Our findings in the main analysis may be a result of a structural change in the type of companies that report under IFRS since it became mandatory for most public companies in Germany. When IFRS was a choice, certain types of firms may have had more incentives to opt to report under IFRS than others. Germany has a large and liquid capital market, which means that large and well established companies have relatively less incentive to switch to IAS/IFRS to attract foreign investors since they can raise capital reporting under German GAAP. However, small information technology and less well established companies may not have the same access to the German capital market, and therefore, have reasons to switch to IAS/IFRS to be able to raise capital. Also, as shown in Table 4, the distribution of companies in different industries changed between the IFRS voluntary $_{\text {periods when the Electronics industry dominated and the IFRS }}$ mandatory period when the financial sector became dominating.

In order to examine whether a self-selection bias in our pre-2005 sample drives the results we also rerun all tests using a sub-sample consisting of companies with firmyear observations in both the IAS and the IFRS period. This sample has 159 observations (92 companies) for the IAS period and 92 observations (92 companies) for the IFRS $_{\text {voluntary }}$ period and 90 observations (90 companies) for the IFRS $\mathrm{S}_{\text {mandatory }}$ period.

As shown in Table 6 Panel A, the results for tests of earnings smoothing and timely loss recognition to some extent support the findings in the analysis using the 
whole sample, although the reduction in accounting quality seems to be considerably lesser. The variability in the change in net income, $\Delta \mathrm{NI}^{*}$, increases significantly between

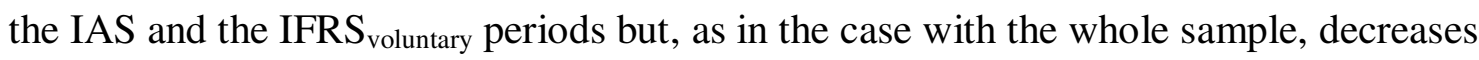

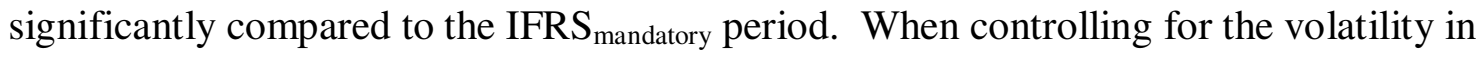
cash flow from operating activities, by using the ratio of net income variability and cash flow from operations variability, we find the same pattern, a significant increase between the IAS and the IFRS voluntary $_{\text {periods followed by a significant between the IFRS }}$ voluntary

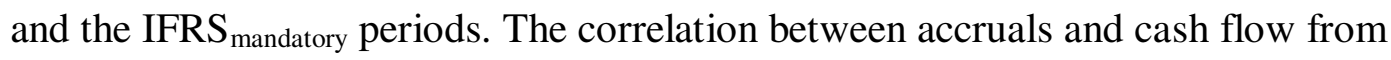
operations shows a significant decrease between the IAS and the IFRS voluntary $_{\text {periods. }}$ The correlation is positive in both of these periods, although it becomes negative in the IFRS $_{\text {mandatory }}$, however, the change is not statistically significant. We find no significant difference in the frequency of reporting small positive earnings across the two periods. Finally, as shown in Table 6 Panel B, we find no significant change in reporting of large negative earnings, indicative for less timely loss recognition. However, contrary to the previous measure, the coefficient of the interaction variable of annual return and negative return is significantly larger for the IFRS $S_{\text {voluntary }}$ period compared to the IAS period. There is no significant difference between the IFRS $S_{\text {voluntary }}$ and the IFRS mandatory $_{\text {periods. }}$ Furthermore, as shown in Table 6 Panel C, the value relevance measures are also contradicting. The overall $\mathrm{R}^{2}$ of the regression models for time periods examined was

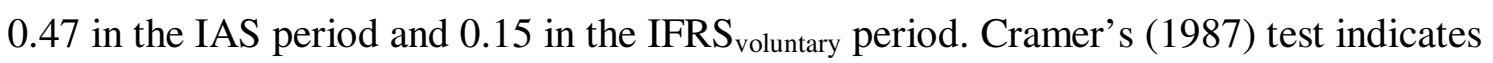
a significant difference in $\mathrm{R}^{2}$ between the two periods on the $1 \%$ level. This is partially

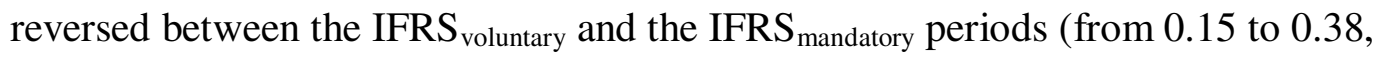
significant on the $5 \%$ level). The analysis of the earnings on returns regressions shows a 
significant increase between IAS period and the IFRS $_{\text {voluntary }}$ periods and a decrease

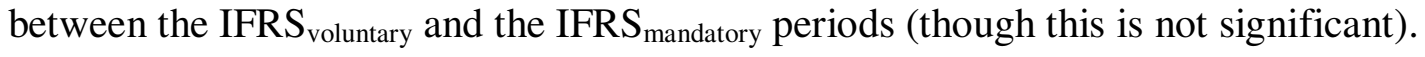
When we analyze the earnings on returns regressions using bad news observations only we find an incremental increase in the value relevance across all three periods.

\section{$<$ Table 6 about here $>$}

We conclude that our measures of earnings management, timely loss recognition, and value relevance using a matched sample are neither providing evidence of an increase nor a decrease in accounting quality between the IAS and the IFRS period.

At the time of the mandatory adoption of IFRS, there is a shift in the structure of the sample, the largest industry group was Electronics up to the end of 2004 after the mandatory adoption in 2005 the largest industry group is now the Financial. We, therefore, rerun our tests excluding financial observations in order to investigate whether the results of our main analysis is driven by companies in the financial sector. As shown in Table 7, there is no qualitative difference in our results from these tests compared to the main analysis using the full sample.

\section{<Table 7 about here>}

In order to analyze whether our results are driven by the new adopters in 2005 , we

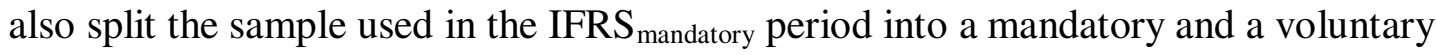
adopter group. Where the mandatory adopters are those who waited to adopt IFRS until it was made mandatory in 2005 and those who adopted IFRS before are classified as voluntary adopters. In addition, when doing this we also excluded all adopters of U.S. GAAP who waited to adopt IFRS until it was made mandatory. The reason for this is that we do not consider these companies as resisting the use of international accounting 
standards, and therefore, they are different from those companies who resist switching from German GAAP to IFRS. As shown in Table 8, we find that there is slightly less variability in residuals of change of net income and the variability of the ratio of the variability of change in residuals of net income and cash flow from operations; however, the differences are not statistically significant. There seem to be more large negative earnings reported by the voluntary adopters but once again, the difference is not statistically significant. The only significant difference between the two groups is found in the value relevance tests, the resisters are consistently showing significantly lower value relevance in all such tests.

\section{$<$ Table 8 about here $>$}

In order to establish that the any decrease in the quality of financial reporting is driven by the excluded set of U.S, GAAP adopters; we also compared these observations to the voluntary adopters. As expected, we did not find any evidence of this. On the contrary, the U.S. GAAP adopters show a significantly higher variability in change in residuals of net income (also when controlling for variability in change in residuals of cash flow from operations), a positive correlation between accruals and cash flow, a significantly lower frequency in reporting small positive incomes. However, the value relevance among these companies was lower than that of the voluntary adopters.

\section{<Table 9 about here>}

\section{Conclusion}

This study compares the characteristics of accounting amounts using a sample of German companies reporting under IAS during 2000-2002, and IFRS during 2003-2004 and 2005-2006. Specifically, we investigate whether there is a change in accounting 
quality during these three time periods as IASB revises existing IAS and issues new IFRS to formulate a set of high quality international accounting standards for global financial reporting purpose. Following prior research, we operationalize accounting quality with earnings smoothing, timely loss recognition, and value relevance metrics. Contrary to our expectations, our results suggest a decrease in accounting quality over the last years. We find that earnings and book value of equity are becoming less value relevant during the IFRS $S_{\text {mandatory }}$ period compared to both the IAS and the IFRS $S_{\text {voluntary }}$ period. The findings on earnings smoothing and timely loss recognition corroborate largely our findings with respect to the value relevance of accounting information. Our results consistently indicate that accounting quality has worsened over time. When using a matched sample we cannot find any clear indication of either an improved or a worsened quality of financial reporting. Further analysis of the 2005 to 2006 period provides some weak indications that this might have been partly driven by new adopters of IFRS in 2005 , however, only the difference in value relevance is statistically significant. We also investigated whether our results were driven by a new dominating industry group, Financials. We find nothing suggesting that this is the case. In sum, it seems that the decrease in accounting quality is mainly driven by changes in accounting standards, not the new adopters in 2005. The implication of this is that the last revisions of IASs and the addition of new IFRSs have caused a decrease the quality of financial reporting in Germany and future research needs to establish which standards drive this development. 


\section{REFERENCES}

Alexander, D. and E.K. Jermakowicz. 2006. "A True and Fair View of the Principles/Rules Debate." Abacus 42: 132-164.

Ashbaugh, H. 2001. "Domestic Accounting Standards, International Accounting Standards, and the Predictability of Earnings. Journal of Accounting Research 39: 417- 434

Barth, M.E., W.H. Beaver, and W.R. Landsman. 1998. "Relative Valuation Roles of Equity Book Value and Net Income as a Function of Financial Health." Journal of Accounting and Economics 25: 1-34.

, W.R. Landsman, and M. Lang. 2005. "International Accounting Standards and Accounting Quality.” Journal of Accounting Research 46: 467-498.

, W.R. Landsman, M. Lang, and C. Williams. 2006. "Accounting Quality: International Accounting Standards and US GAAP.” Working paper.

Bartov, E. and M. Kim. 2005. "Comparative value relevance among German, U.S. and international accounting standards: a German stock market perspective." Journal of Accounting, Auditing \& Finance 20: 95-119.

Basu, S., 1997. "The Conservatism Principle and The Asymmetric Timeliness of Earnings." Journal of Accounting and Economics (24): 3-37.

Christensen, H.B., E. Lee, and M. Walker. 2007. "Incentives or Standards: What Determine Accounting Quality Changes Around IFRS Adoption?" Working Paper Manchester Business School.

Collins, D.W., E.L. Maydew, and I.S. Weiss. 1997. "Changes in the Value-Relevance of Earnings and Book Values over the Past Forty Years." Journal of Accounting and Economics (24): 39-67.

Cramer, J.S. 1987. "Mean and Variance of $\mathrm{R}^{2}$ in Small and Moderate Samples." Journal of Econometrics. 35: 253-266.

Daske, H. 2006. "Economic Benefits of Adopting IFRS or US-GAAP - Have the Expected Cost of Equity Capital Really Decreased?" Journal of Business Finance \& Accounting. 33: 329-373.

Easton, P. 1985. "Accounting Earnings and Security Valuation: Empirical Evidence of Fundamental Links." Journal of Accounting Research. 23 (Supplement): 54-77.

Hayn, C. 1995. "The information content of losses." Journal of Accounting and Economics 20: 125-153. 
Hung, M., and K.R. Subramanyam. 2007. "Financial statement effects of adopting international accounting standards: the case of Germany." Review of Accounting Studies. 12: 623-657.

Jermakowicz, E.K., J. Prather-Kinsey, and I. Wulf. 2007. "The Value Relevance of Accounting Income Reported by DAX-30 German Companies." Journal of International Financial Management and Accounting. 18: 151-191.

Lang, M., J. Raedy, and M. Yetman. 2003. "How Representative are Firms that are Cross Listed in the United States?" An Analysis of Accounting Quality." Journal of Accounting Research. 41: 363-386.

Lang, M; J. Raedy, and W. Wilson. 2006. "Earnings Management and Cross-Listing: Are Reconciled Earnings Comparable to U.S. Earnings?” Journal of Accounting \& Economics. 42: 255-283.

Leuz, C., and R. E. Verrecchia. 2000. The Economic Consequences of Increased Disclosure. Journal of Accounting Research. 38 (Supplement): 91-124.

Leuz, C., D. Nanda, and P. Wysocki. 2003. "Earnings Management and Investor Protection: An International Comparison.” Journal of Financial Economics 69: 505-527.

Ohlson, J.A. 1995. Earnings, book values, and dividends in security valuation. Contemporary Accounting Research 11: 661-687.

Pagano, M., A. Röell, and J. Zehner. 2002. ’The Geography of Equity Listings: Why do Companies List Abroad?" Journal of Finance. 57: 2651-2694.

Platikanova, P. and C. Nobes. 2006. "Was the Introduction of IFRS in Europe ValueRelevant?" Working Paper University Pompeu Fabra and University of Reading.

Schipper, K. 2005. "The Introduction of International Accounting Standards in Europe: Implications for International Convergence". European Accounting Review 14:101-126.

Soderstrom, N. S. and K. J. Sun. 2007. "IFRS Adoption and Accounting Quality: A Review." European Accounting Review 16:675-702.

Tarca, A. 2004. "International Convergence of Accounting Practices: Choosing Between IAS and US GAAP." Journal of International Financial Management and Accounting. 15: 60-91.

Whittington, G. 2005. "The Adoption of International Accounting Standards in the European Union." European Accounting Review 14:127-153. 
Table 1: Summary of Revisions of IAS and IFRS over Time

\begin{tabular}{|c|c|c|c|c|}
\hline \multicolumn{5}{|c|}{ Panel A: Revisions During the IAS period } \\
\hline Standard & $\begin{array}{l}\text { Issued/ } \\
\text { revised } \\
\text { Year }\end{array}$ & In effect & Focus & Revision Made \\
\hline IAS 12 & 2000 & 2001 & $\begin{array}{l}\text { Income } \\
\text { Taxes }\end{array}$ & $\begin{array}{l}\text { The standard was amended to include guidance on } \\
\text { accounting for tax consequences of dividends and } \\
\text { other distributions made by the reporting parent } \\
\text { company. }\end{array}$ \\
\hline IAS 19 & 2000 & 2001 & $\begin{array}{l}\text { Employee } \\
\text { benefits }\end{array}$ & $\begin{array}{l}\text { Revised to include and regulate more the } \\
\text { retirement benefit costs only. }\end{array}$ \\
\hline IAS 40 & 2000 & 2001 & $\begin{array}{l}\text { Investment } \\
\text { property }\end{array}$ & $\begin{array}{l}\text { Was an attempt to impose fair value measurement } \\
\text { of investment property, ended up allowing it as an } \\
\text { alternative to historical cost accounting. }\end{array}$ \\
\hline \multicolumn{5}{|c|}{ Panel B: Revisions During the IFRS voluntary period } \\
\hline Standard & $\begin{array}{l}\text { Issued/ } \\
\text { revised } \\
\text { Year }\end{array}$ & In effect & Focus & Revision Made \\
\hline IAS 10 & 2003 & 2004 & $\begin{array}{l}\text { Events after } \\
\text { the reporting } \\
\text { period }\end{array}$ & $\begin{array}{l}\text { Regulates the reporting of events after the } \\
\text { reporting period. }\end{array}$ \\
\hline IAS 17 & 2003 & 2004 & Leases & $\begin{array}{l}\text { Initial direct and incremental costs by lessors in } \\
\text { negotiating leases must be recognized over the } \\
\text { lease term. }\end{array}$ \\
\hline IAS 32 & 2003 & $2005^{*}$ & $\begin{array}{l}\text { Presentation } \\
\text { of financial } \\
\text { instruments }\end{array}$ & $\begin{array}{l}\text { Additional guidance on measurement of the } \\
\text { components of compound instruments on initial } \\
\text { recognition and to group all guidance on financial } \\
\text { instruments in one standard }\end{array}$ \\
\hline IAS 33 & 2003 & $2005^{*}$ & $\begin{array}{l}\text { Earnings per } \\
\text { share }\end{array}$ & $\begin{array}{l}\text { Clarifying the standard and eliminate alternatives } \\
\text { allowed by the standard. }\end{array}$ \\
\hline IAS 41 & 2001 & 2003 & Agriculture & $\begin{array}{l}\text { Regulates accounting for agricultural assets. These } \\
\text { types of assets were previously not covered by } \\
\text { other IASs. }\end{array}$ \\
\hline IAS 36 & 2004 & 2004 & $\begin{array}{l}\text { Impairment } \\
\text { of assets }\end{array}$ & $\begin{array}{l}\text { Requires measurement of recoverable amount of } \\
\text { intangible assets with an indefinite useful life on an } \\
\text { annual basis (including goodwill and intangible } \\
\text { assets not yet available for use). }\end{array}$ \\
\hline IAS 38 & 2004 & 2004 & $\begin{array}{l}\text { Intangible } \\
\text { assets }\end{array}$ & $\begin{array}{l}\text { The assumption that all assets' useful life is finite } \\
\text { is abolished. In addition, intangible assets with } \\
\text { infinite useful life should not be amortized. }\end{array}$ \\
\hline IFRS 1 & 2003 & 2004 & $\begin{array}{l}\text { First-time } \\
\text { adoption of } \\
\text { IFRS }\end{array}$ & Sets out the procedures for first-time Adoption. \\
\hline IFRS 3 & 2004 & 2004 & $\begin{array}{l}\text { Business } \\
\text { combinations }\end{array}$ & $\begin{array}{l}\text { Prohibits the use of the pooling of interests method } \\
\text { for business combinations. Goodwill is initially } \\
\text { defined as the net fair value of acquired assets and } \\
\text { liabilities. Goodwill etc. with infinite lives are mot } \\
\text { amortized. Also see IAS } 36 \text { and IAS } 38 \text {. }\end{array}$ \\
\hline IAS 1 & 2003 & $2005^{*}$ & $\begin{array}{l}\text { Presentation } \\
\text { of Financial } \\
\text { Statements }\end{array}$ & $\begin{array}{l}\text { Mostly transferring the policies application related } \\
\text { to changes in accounting estimates and errors to } \\
\text { IAS } 8 \text { while the presentation issues is transferred to } \\
\text { IAS } 1 \text {. }\end{array}$ \\
\hline
\end{tabular}




\begin{tabular}{|c|c|c|c|c|}
\hline Standard & $\begin{array}{l}\text { Issued/ } \\
\text { revised } \\
\text { Year }\end{array}$ & In effect & Focus & Revision Made \\
\hline IAS 2 & 2003 & $2005^{*}$ & Inventories & $\begin{array}{l}\text { The main change is the prohibition of LIFO as a } \\
\text { cost formula. }\end{array}$ \\
\hline IAS 8 & 2003 & $2005^{*}$ & $\begin{array}{l}\text { Accounting } \\
\text { policies, } \\
\text { changes in } \\
\text { accounting } \\
\text { estimates and } \\
\text { errors }\end{array}$ & Please refer to revisions described for IAS 1. \\
\hline \multirow[t]{3}{*}{ IAS 16} & 2004 & $2005^{*}$ & $\begin{array}{l}\text { Property, } \\
\text { plant, and } \\
\text { equipment }\end{array}$ & $\begin{array}{l}\text { Costs of dismantlement, removal or restoration are } \\
\text { included in capitalized amounts. }\end{array}$ \\
\hline & & & & $\begin{array}{l}\text { Fair value revaluation only if this is reliably } \\
\text { measurable. }\end{array}$ \\
\hline & & & & $\begin{array}{l}\text { Depreciation must start when the asset is available } \\
\text { for use and continues regardless if the asset is idle } \\
\text { or not. }\end{array}$ \\
\hline IAS 19 & 2004 & $2006^{*}$ & $\begin{array}{l}\text { Employee } \\
\text { benefits }\end{array}$ & $\begin{array}{l}\text { Revised to permit recognition of actuarial gain and } \\
\text { losses in equity and to require additional } \\
\text { disclosure. }\end{array}$ \\
\hline IAS 21 & 2003 & $2005^{*}$ & $\begin{array}{l}\text { Changes in } \\
\text { foreign } \\
\text { exchange } \\
\text { rates }\end{array}$ & $\begin{array}{l}\text { Removal of a limited option to capitalize exchange } \\
\text { rate differences resulting from severe devaluation } \\
\text { or depreciation of a currency against which there is } \\
\text { no means of hedging. }\end{array}$ \\
\hline IAS 24 & 2003 & $2005^{*}$ & $\begin{array}{l}\text { Related party } \\
\text { disclosures }\end{array}$ & $\begin{array}{l}\text { Requires disclosure of compensation to key } \\
\text { management employees and expands the definition } \\
\text { of "related party" by adding joint ventures, etc. }\end{array}$ \\
\hline IAS 27 & 2003 & $2005^{*}$ & $\begin{array}{l}\text { Consolidated } \\
\text { and separate } \\
\text { financial } \\
\text { statements }\end{array}$ & $\begin{array}{l}\text { Minority interests are now presented within the } \\
\text { equity as a separate line item. }\end{array}$ \\
\hline IAS 28 & 2003 & $2005^{*}$ & $\begin{array}{l}\text { Investments } \\
\text { in associates }\end{array}$ & $\begin{array}{l}\text { Investors must not only consider the carrying } \\
\text { amount the investment but also other long-term } \\
\text { interests in the associate when recognizing its share } \\
\text { of losses of the associate. }\end{array}$ \\
\hline IAS 31 & 2003 & $2005^{*}$ & $\begin{array}{l}\text { Interests in } \\
\text { joint } \\
\text { ventures }\end{array}$ & $\begin{array}{l}\text { Investors must disclose the method used to } \\
\text { recognize its interest in jointly controlled entities } \\
\text { (proportional consolidation or the equity method). }\end{array}$ \\
\hline IAS 39 & 2004 & $2005^{*}$ & $\begin{array}{l}\text { Financial } \\
\text { instruments: } \\
\text { recognition } \\
\text { and } \\
\text { measurement }\end{array}$ & $\begin{array}{l}\text { Added fair value accounting for a hedge of the } \\
\text { interest rate exposure of a portfolio of financial } \\
\text { assets and liabilities. }\end{array}$ \\
\hline IAS 40 & 2004 & $2005^{*}$ & $\begin{array}{l}\text { Investment } \\
\text { property }\end{array}$ & $\begin{array}{l}\text { Defining the concept "investment property" and } \\
\text { impose a consistent use of the fair value or the cost } \\
\text { model. }\end{array}$ \\
\hline IFRS 2 & 2004 & $2005^{*}$ & $\begin{array}{l}\text { Share-based } \\
\text { payment }\end{array}$ & $\begin{array}{l}\text { Require recognition of all share-based payment } \\
\text { transactions using a fair value measurement basis. }\end{array}$ \\
\hline
\end{tabular}




\begin{tabular}{lllll}
\hline Panel B: Revisions During the IFRS voluntary period cont. \\
\hline Standard & $\begin{array}{l}\text { Issued/ } \\
\text { revised } \\
\text { Year }\end{array}$ & In effect & Focus & Revision Made \\
\hline IFRS 4 & 2004 & $2005^{*}$ & $\begin{array}{l}\text { Insurance } \\
\text { contracts }\end{array}$ & $\begin{array}{l}\text { Prohibits catastrophe and equalization reserves. } \\
\text { Requires testing of the adequacy of recognized } \\
\text { insurance liabilities and impairment tests of } \\
\text { reinsurance assets. }\end{array}$ \\
\hline IFRS 5 & 2004 & $2005^{*}$ & $\begin{array}{l}\text { Non-current } \\
\text { assets held } \\
\text { for sale and } \\
\text { discontinued } \\
\text { operations }\end{array}$ & $\begin{array}{l}\text { Prescribes accounting for assets held for sale and } \\
\text { the presentation and disclosure of discontinued } \\
\text { operations. }\end{array}$ \\
\hline Panel C: Revisions During the IFRS mandatory period \\
\hline
\end{tabular}

\begin{tabular}{lllll}
\hline Standard & $\begin{array}{l}\text { Issued/ } \\
\text { revised } \\
\text { Year }\end{array}$ & In effect & Focus & Revision Made \\
\hline IAS 39 & 2005 & 2006 & $\begin{array}{l}\text { Financial } \\
\text { instruments: } \\
\text { recognition } \\
\text { and } \\
\text { measurement }\end{array}$ & $\begin{array}{l}\text { Restricted the use of the "fair value option" to } \\
\text { eliminate accounting or economic mismatches. }\end{array}$ \\
\hline IFRS 6 & 2005 & 2006 & $\begin{array}{l}\text { Exploration } \\
\text { for and } \\
\text { evaluation of } \\
\text { mineral } \\
\text { resources }\end{array}$ & $\begin{array}{l}\text { Regulates the financial reporting of mineral } \\
\text { resources until IASB has completed a } \\
\text { comprehensive project of this. }\end{array}$ \\
\hline IFRS 7 & 2006 & 2007 & $\begin{array}{l}\text { Financial } \\
\text { instruments } \\
\text { disclosure }\end{array}$ & $\begin{array}{l}\text { Require disclosure of information on the } \\
\text { significance of financial instruments for a } \\
\text { company's financial position and profitability. }\end{array}$ \\
\hline IFRS 8 & 2006 & $2009 *$ & $\begin{array}{l}\text { Operating } \\
\text { Segments }\end{array}$ & $\begin{array}{l}\text { Extends and change the scope of segment } \\
\text { reporting. }\end{array}$ \\
\hline "Earlier application is encouraged. & & \\
\hline
\end{tabular}


Table 2: Sample Selection Process.

\begin{tabular}{|l|cc|cc|cr|}
\hline & \multicolumn{2}{|r|}{ IAS } & \multicolumn{2}{|c|}{ IFRS } & \multicolumn{2}{|c|}{ IFRS } \\
& Firms & $\begin{array}{c}\text { Firm- } \\
\text { Years }\end{array}$ & Firms & $\begin{array}{r}\text { Firm- } \\
\text { Years }\end{array}$ & Firms & $\begin{array}{r}\text { Firm- } \\
\text { Years }\end{array}$ \\
\hline $\begin{array}{l}\text { From Datastream } \\
\begin{array}{l}\text { Excluded observations } \\
\text { due to missing data } \\
\text { Total sample }\end{array}\end{array}$ & 290 & 570 & 327 & 327 & 571 & 571 \\
\hline
\end{tabular}


Table 3: Analysis of Industry Specialization

\begin{tabular}{l|rr|rr|rr}
\hline & \multicolumn{2}{|c|}{ IAS } & & IFRS & \\
& & & & & \\
& 0 & $0 \%$ & 0 & $0 \%$ & 1 & $0 \%$ \\
\hline Aerospace & 3 & $2 \%$ & 4 & $2 \%$ & 7 & $2 \%$ \\
Apparel & 4 & $3 \%$ & 4 & $2 \%$ & 6 & $1 \%$ \\
Automotive & 0 & $0 \%$ & 1 & $0 \%$ & 6 & $1 \%$ \\
Beverages & 4 & $4 \%$ & 5 & $2 \%$ & 12 & $3 \%$ \\
Chemicals & 4 & $4 \%$ & 9 & $4 \%$ & 20 & $4 \%$ \\
Construction & 2 & $2 \%$ & 2 & $1 \%$ & 6 & $1 \%$ \\
Diversified & 5 & $5 \%$ & 10 & $5 \%$ & 21 & $5 \%$ \\
Drugs, cosmetics and health care & 3 & $3 \%$ & 5 & $2 \%$ & 11 & $2 \%$ \\
Electrical & 14 & $13 \%$ & 31 & $15 \%$ & 55 & $12 \%$ \\
Electronics & 12 & $11 \%$ & 22 & $11 \%$ & 65 & $15 \%$ \\
Financials & 1 & $1 \%$ & 1 & $0 \%$ & 6 & $1 \%$ \\
Food & 10 & $9 \%$ & 23 & $11 \%$ & 44 & $10 \%$ \\
Machinery and equipment & 1 & $1 \%$ & 1 & $0 \%$ & 1 & $0 \%$ \\
Metal producers & 1 & $1 \%$ & 3 & $1 \%$ & 5 & $1 \%$ \\
Metal product manufacturers & 0 & $0 \%$ & 2 & $1 \%$ & 2 & $0 \%$ \\
Oil, gas, coal and related services & 0 & $0 \%$ & 2 & $1 \%$ & 5 & $1 \%$ \\
Paper & 0 & $0 \%$ & 2 & $1 \%$ & 3 & $1 \%$ \\
Printing and publishing & 6 & $6 \%$ & 10 & $5 \%$ & 16 & $4 \%$ \\
Recreation & 2 & $2 \%$ & 7 & $3 \%$ & 13 & $3 \%$ \\
Retailers & 2 & $2 \%$ & 2 & $1 \%$ & 4 & $1 \%$ \\
Textiles & 2 & $2 \%$ & 2 & $1 \%$ & 3 & $1 \%$ \\
Transportation & 4 & $4 \%$ & 6 & $3 \%$ & 14 & $3 \%$ \\
Utilities & 27 & $25 \%$ & 50 & $25 \%$ & 122 & $27 \%$ \\
Miscellaneous & 107 & & 204 & & 451 & \\
& & & & & &
\end{tabular}


Table 4: Descriptive Statistics

\begin{tabular}{|c|c|c|c|c|c|c|c|c|c|}
\hline \multirow[b]{3}{*}{ Test Variables } & \multicolumn{3}{|c|}{ IAS Firms $\mathbf{N}=187$} & \multicolumn{3}{|c|}{ IFRS $_{\mathrm{V}}$ Firms N=204 } & \multicolumn{3}{|c|}{ IFRS $_{M}$ Firms N=448 } \\
\hline & Mean & Median & $\begin{array}{l}\text { Standard } \\
\text { deviation }\end{array}$ & Mean & Median & $\begin{array}{l}\text { Standard } \\
\text { deviation }\end{array}$ & Mean & Median & $\begin{array}{l}\text { Standard } \\
\text { deviation }\end{array}$ \\
\hline & & & & & & & & & \\
\hline $\mathrm{EPS}^{1}$ & -0.162 & 0.022 & 0.444 & $-0.034^{* * * *}$ & $0.052^{* * *}$ & 0.300 & $0.019^{* *}$ & $0.058^{* *}$ & 0.226 \\
\hline BVPS $^{2}$ & 0.818 & 0.583 & 0.699 & 0.737 & 0.670 & 0.511 & $0.642^{* *}$ & $0.548^{* * *}$ & 0.481 \\
\hline Return $^{3}$ & -36.298 & -39.190 & 37.876 & $27.005^{* * *}$ & $7.715^{* * *}$ & 61.345 & 24.681 & $17.535^{\text {*** }}$ & 49.371 \\
\hline$\Delta \mathrm{NI}^{4}$ & -0.054 & -0.005 & 0.202 & $0.255^{* * *}$ & $0.013^{* * *}$ & 0.223 & 0.011 & $0.007^{* * *}$ & 0.136 \\
\hline$\Delta \mathrm{CFO}^{5}$ & 0.019 & 0.010 & 0.121 & 0.017 & 0.009 & 0.124 & $-0.006^{* *}$ & $-0.003^{* * *}$ & 0.110 \\
\hline SPOS $^{7}$ & 0.123 & 0.000 & 0.329 & 0.118 & 0.000 & 0.323 & 0.107 & 0.000 & 0.310 \\
\hline Lneg $^{8}$ & 0.150 & 0.000 & 0.358 & $0.083^{* *}$ & $0.000^{* *}$ & 0.277 & 0.051 & 0.000 & 0.221 \\
\hline Control Variables & & & & & & & & & \\
\hline $\mathrm{LEV}^{9}$ & 0.579 & 0.614 & 0.252 & 0.578 & 0.608 & 0.263 & 0.557 & 0.575 & 0.246 \\
\hline Growth $^{10}$ & 0.294 & 0.056 & 0.714 & $0.092^{* * *}$ & $0.047^{*}$ & 0.350 & $0.184^{* *}$ & $0.090^{\text {**** }}$ & 0.508 \\
\hline Eissue $^{11}$ & 0.053 & 0.000 & 0.227 & 0.082 & 0.000 & 0.266 & 0.119 & 0.000 & 0.420 \\
\hline Dissue $^{12}$ & 0.421 & 0.037 & 1.682 & 0.275 & 0.012 & 1.503 & 0.333 & $0.059^{* * * *}$ & 1.585 \\
\hline Turn $^{13}$ & 1.093 & 0.929 & 0.829 & 1.191 & $1.118^{* *}$ & 0.778 & 1.061 & $1.012^{* *}$ & 0.716 \\
\hline $\mathrm{CFO}^{15}$ & 0.044 & 0.057 & 0.117 & $0.074^{* *}$ & $0.075^{* * *}$ & 0.123 & 0.046 & $0.055^{* * *}$ & 0.104 \\
\hline NUMEX $^{16}$ & 2.337 & 2.000 & 1.668 & 2.098 & 2.000 & 1.365 & 1.920 & $2.000^{*}$ & 1.211 \\
\hline $\mathrm{AUD}^{17}$ & 0.658 & 1.000 & 0.476 & 0.598 & 1.000 & 0.492 & 0.596 & 1.000 & 0.491 \\
\hline $\mathrm{XLIST}^{18}$ & 0.016 & 0.000 & 0.126 & 0.010 & 0.000 & 0.098 & 0.009 & 0.000 & 0.094 \\
\hline $\mathrm{FF}^{19}$ & 91.584 & 15.846 & $165,240.000$ & $60.201^{* *}$ & $10.541^{* *}$ & $134,479.500$ & 46.717 & 11.719 & $111,953.000$ \\
\hline
\end{tabular}

${ }^{1}$ EPS is earnings per share at year end of the fiscal year deflated by the share price 6 months after the preceding fiscal year end

${ }^{2}$ BVPS is the book value of shareholders' equity per share at the end of the fiscal year deflated by the share price 6 months after the preceding fiscal year end.

${ }^{3}$ Return is the annual return of company $i$ at time $t$.

${ }_{5}^{4} \Delta \mathrm{NI}$ is the change in annual earnings scaled by total assets.

${ }^{5} \triangle \mathrm{CF}$ is the change in cash flow from operating activities scaled by total assets.

${ }^{6} \mathrm{ACC}$ is earnings less cash flow from operating activities scaled by total assets.

${ }^{7}$ SPOS is a dummy variable taking on the value 1 for observations for which the annual earnings scaled by total assets is between 0 and 0.01 , and 0 otherwise.

${ }^{8}$ Lneg is a dummy variable taking on the value 1 for observations for which the annual earnings scaled by total assets is less than -0.20 , and 0 otherwise.

${ }^{9}$ LEV is total liabilities divided by shareholders' equity.

${ }^{10}$ Growth is the percentage change in sales.

${ }^{11}$ Eissue is the percentage change in common shareholders' stock. 
${ }^{12}$ Dissue is the percentage change in total liabilities.

${ }^{13}$ Turn is sales divided by total assets.

${ }^{14}$ Size is the natural log of total assets.

${ }^{15} \mathrm{CFO}$ is the cash flow from operating activities scaled by total assets.

${ }^{16}$ NUMEX is the number of stock exchange listings.

${ }^{17}$ AUD is an indicator taking on the value of 1 if the firm's auditor is PwC, KPMG, Arthur Andersen, E\&Y, or D\&T, and 0 otherwise.

${ }^{18}$ XLIST is an indicator taking on the value of 1 if the firm is listed on any U.S. stock exchange and 0 otherwise.

${ }^{19} \mathrm{FF}$ is the free float measured as the average number of shares traded the last day of the month during the fiscal year divided by number of common shares outstanding at the fiscal year end, divided by 1,000 .

Asterisks indicate that there is significantly different from the previous time period using a two-tailed t-test: ${ }^{*} \mathrm{p}<0.1,{ }^{* *} \mathrm{p}<0.05$, and ${ }^{* * *} \mathrm{p}<0.01$. 
Table 5: Analysis of Accounting Quality

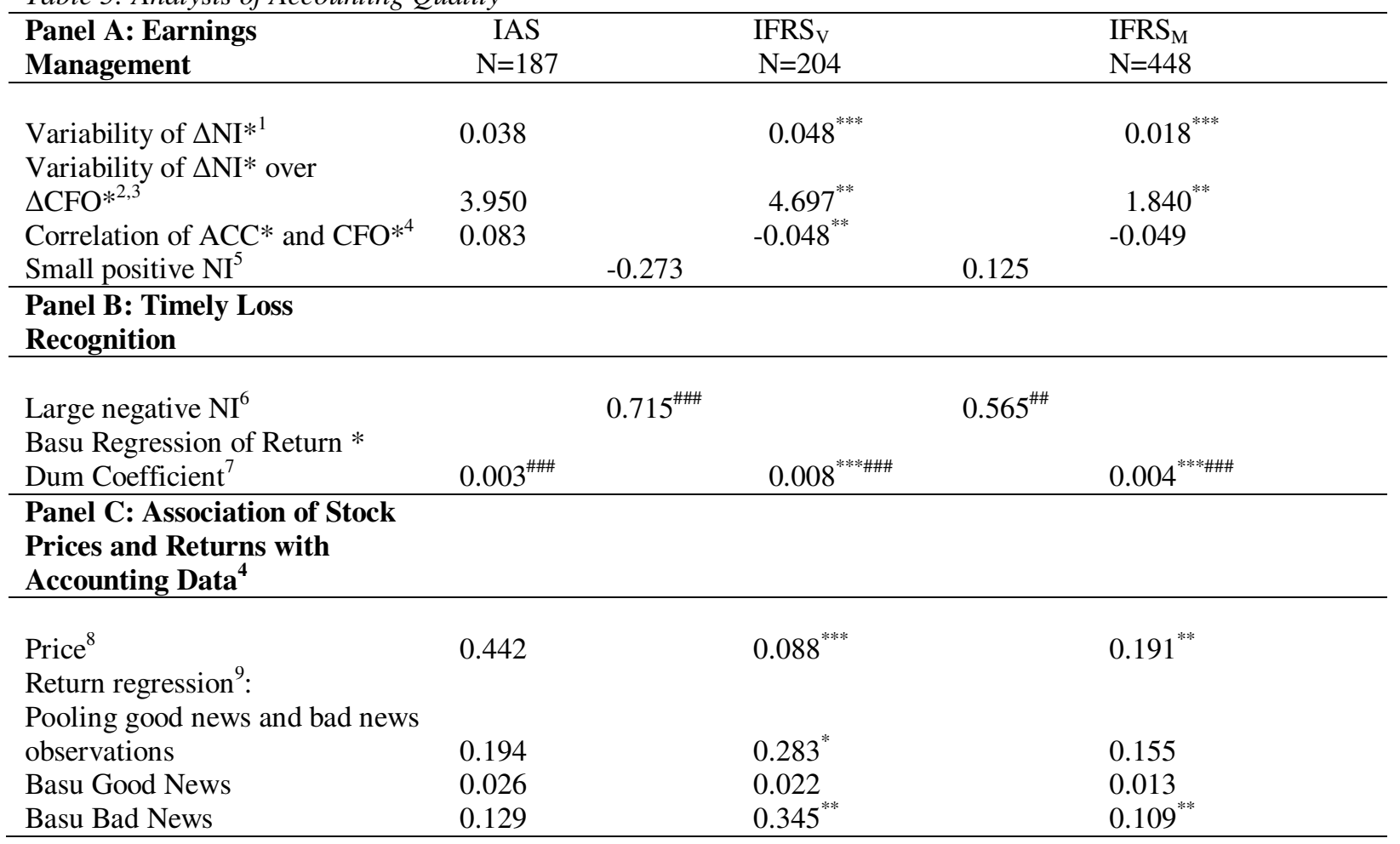

$*, * *, * * *$ Significantly different between each category at the $0.01,0.05$, and the 0.10 respectively (two-tailed)

\#, \#, \#\#" Significantly different from zero at the $0.01,0.05$, and the 0.10 respectively (two-tailed)

${ }^{1} \Delta \mathrm{NI} *$ is the variance of residuals from a regression of the $\Delta \mathrm{NI}$ on the control variables.

${ }^{2} \triangle \mathrm{CFO} *$ is the variance of residuals from a regression of the $\Delta \mathrm{NI}$ on the control variables.

${ }^{3}$ Variability of $\Delta \mathrm{NI}^{*}$ over $\Delta \mathrm{CFO} *$ is the ratio of $\Delta \mathrm{NI}^{*}$ divided by $\triangle \mathrm{CFO} *$.

${ }^{4}$ Correlation of $\mathrm{ACC}^{*}$ and $\mathrm{CFO} *$ is the partial Spearman correlation between the residuals from the ACC and $\mathrm{CFO}$ regression.

${ }^{5}$ SPOS is a dummy variable taking on the value 1 for observations for which the annual earnings scaled by total assets is between 0 and 0.01 , and 0 otherwise.

${ }^{6}$ Lneg is a dummy variable taking on the value 1 for observations for which the annual earnings scaled by total assets is less than -0.20 , and 0 otherwise.

${ }^{7}$ The regression is $E P S=\beta_{0}+\beta_{1} R+\beta_{2} D U M+\beta_{3} R * D U M+\varepsilon$ where $E P S$ is annual earnings per share deflated by share price at the beginning of the period, $R$ is annual return, and $D U M$ takes on the value 1 if the return is negative and 0 otherwise.

${ }^{8}$ The regression is $P=\beta_{0}+\beta_{1} E P S+\beta_{2} B V P S+\varepsilon$ where $P$ is price as of three months after the fiscal year end, EPS is earnings per share and $B V P S$ is the book value of shareholders' equity per share. All variables are scaled by share price six months after the preceding year-end.

${ }^{9}$ The Basu good and bad news regression is $E P S=\beta_{0}+\beta_{1} R+\varepsilon$, where EPS is earnings per share deflated by price at the beginning of the year and $R$ is the annual return. Good news observations are those for which $R$ is positive and bad news are those for which return is negative. We winsorize all continuous variables at the $1 \%$ level to control for outliers. 
Table 6: Analysis of Accounting Quality Using a Sub-Sample of voluntary IFRS adopters.

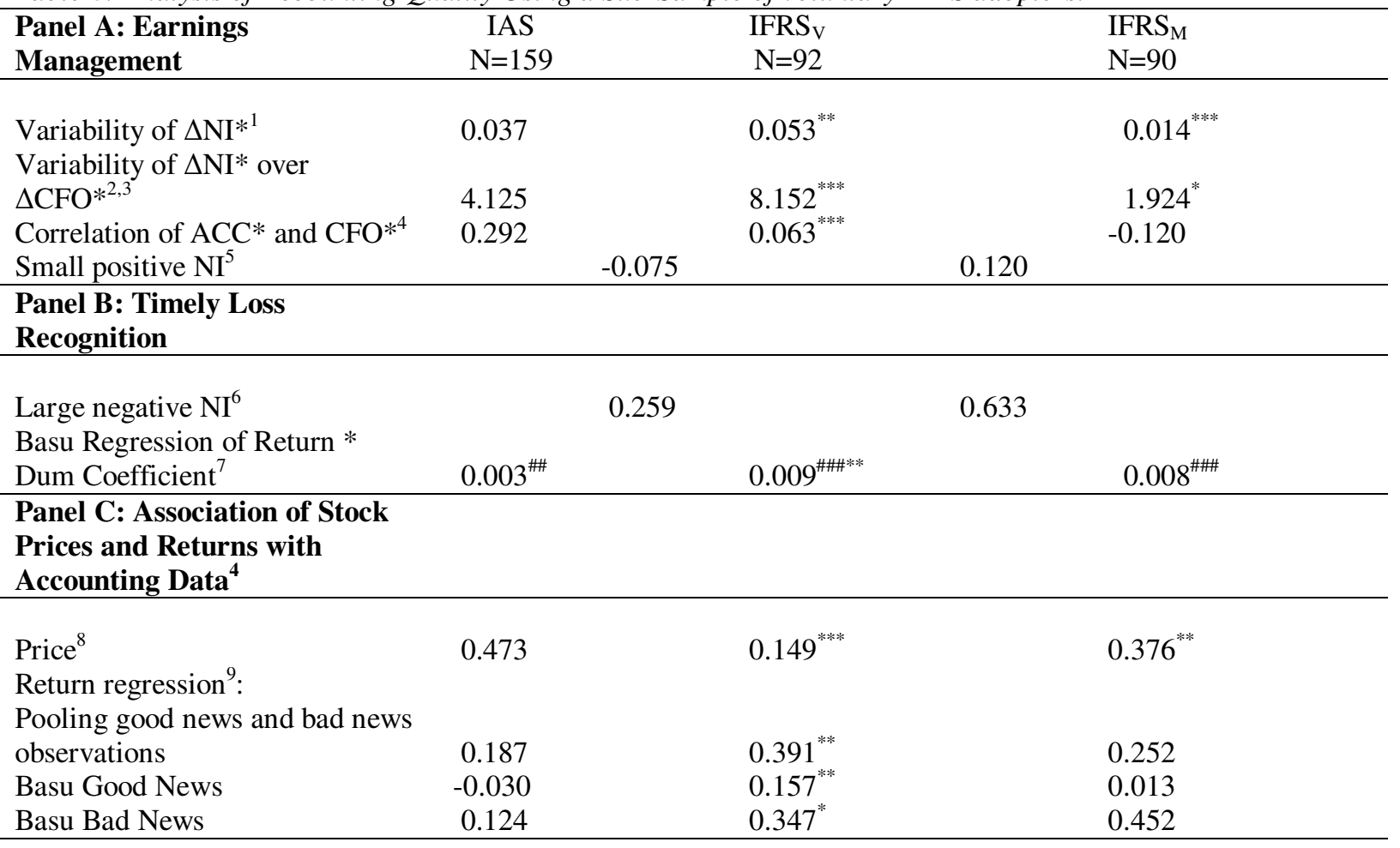

$*, * *, * * *$ Significantly different between each category at the $0.01,0.05$, and the 0.10 respectively (two-tailed)

\#, \#, \#\#" Significantly different from zero at the $0.01,0.05$, and the 0.10 respectively (two-tailed)

${ }^{1} \Delta \mathrm{NI} *$ is the variance of residuals from a regression of the $\Delta \mathrm{NI}$ on the control variables.

${ }^{2} \triangle \mathrm{CFO} *$ is the variance of residuals from a regression of the $\Delta \mathrm{NI}$ on the control variables.

${ }^{3}$ Variability of $\Delta \mathrm{NI}^{*}$ over $\Delta \mathrm{CFO} *$ is the ratio of $\Delta \mathrm{NI}^{*}$ divided by $\triangle \mathrm{CFO} *$.

${ }^{4}$ Correlation of $\mathrm{ACC}^{*}$ and $\mathrm{CFO} *$ is the partial Spearman correlation between the residuals from the ACC and $\mathrm{CFO}$ regression.

${ }^{5}$ SPOS is a dummy variable taking on the value 1 for observations for which the annual earnings scaled by total assets is between 0 and 0.01 , and 0 otherwise.

${ }^{6}$ Lneg is a dummy variable taking on the value 1 for observations for which the annual earnings scaled by total assets is less than -0.20 , and 0 otherwise.

${ }^{7}$ The regression is $E P S=\beta_{0}+\beta_{1} R+\beta_{2} D U M+\beta_{3} R * D U M+\varepsilon$ where $E P S$ is annual earnings per share deflated by share price at the beginning of the period, $R$ is annual return, and $D U M$ takes on the value 1 if the return is negative and 0 otherwise.

${ }^{8}$ The regression is $P=\beta_{0}+\beta_{1} E P S+\beta_{2} B V P S+\varepsilon$ where $P$ is price as of three months after the fiscal year end, EPS is earnings per share and $B V P S$ is the book value of shareholders' equity per share. All variables are scaled by share price six months after the preceding year-end.

${ }^{9}$ The Basu good and bad news regression is $E P S=\beta_{0}+\beta_{1} R+\varepsilon$, where EPS is earnings per share deflated by price at the beginning of the year and $R$ is the annual return. Good news observations are those for which $R$ is positive and bad news are those for which return is negative. We winsorize all continuous variables at the $1 \%$ level to control for outliers. 
Table 7: Analysis of Accounting Quality Excluding Firm-Year Observations from the Financial Industry

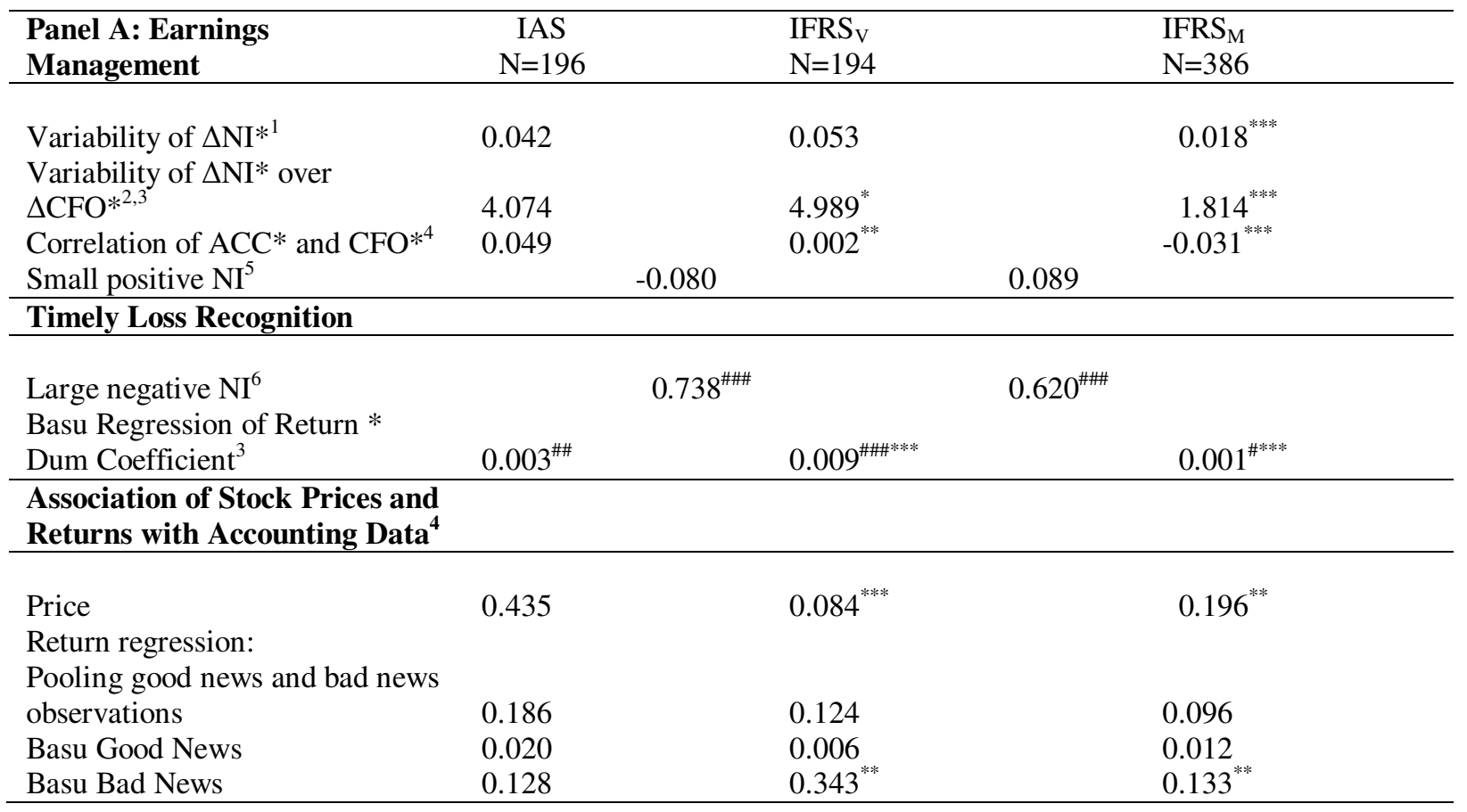

${ }^{*}, * *, * * *$ Significantly different between each category at the $0.01,0.05$, and the 0.10 respectively (two-tailed)

\#, \#, \#\#\# Significantly different from zero at the $0.01,0.05$, and the 0.10 respectively (two-tailed)

${ }^{1} \Delta \mathrm{NI} *$ is the variance of residuals from a regression of the $\Delta \mathrm{NI}$ on the control variables.

${ }^{2} \Delta \mathrm{CFO} *$ is the variance of residuals from a regression of the $\Delta \mathrm{NI}$ on the control variables.

${ }^{3}$ Variability of $\Delta \mathrm{NI}^{*}$ over $\Delta \mathrm{CFO} *$ is the ratio of $\Delta \mathrm{NI}^{*}$ divided by $\Delta \mathrm{CFO} *$.

${ }^{4}$ Correlation of ACC* and CFO* is the partial Spearman correlation between the residuals from the ACC and $\mathrm{CFO}$ regression.

${ }^{5}$ SPOS is a dummy variable taking on the value 1 for observations for which the annual earnings scaled by total assets is between 0 and 0.01 , and 0 otherwise.

${ }^{6}$ Lneg is a dummy variable taking on the value 1 for observations for which the annual earnings scaled by total assets is less than -0.20 , and 0 otherwise.

${ }^{7}$ The regression is $E P S=\beta_{0}+\beta_{1} R+\beta_{2} D U M+\beta_{3} R * D U M+\varepsilon$ where EPS is annual earnings per share deflated by share price at the beginning of the period, $R$ is annual return, and $D U M$ takes on the value 1 if the return is negative and 0 otherwise.

${ }^{8}$ The regression is $P=\beta_{0}+\beta_{1} E P S+\beta_{2} B V P S+\varepsilon$ where $P$ is price as of three months after the fiscal year end, EPS is earnings per share and $B V P S$ is the book value of shareholders' equity per share. All variables are scaled by share price six months after the preceding year-end.

${ }^{9}$ The Basu good and bad news regression is $E P S=\beta_{0}+\beta_{1} R+\varepsilon$, where EPS is earnings per share deflated by price at the beginning of the year and $R$ is the annual return. Good news observations are those for which $R$ is positive and bad news are those for which return is negative. We winsorize all continuous variables at the $1 \%$ level to control for outliers. 
Table 8: Analysis of Accounting Quality Using Observations from the 2005-2006 Period, Comparing Voluntary Adopters of IFRS and Mandatory Adopters of IFRS.

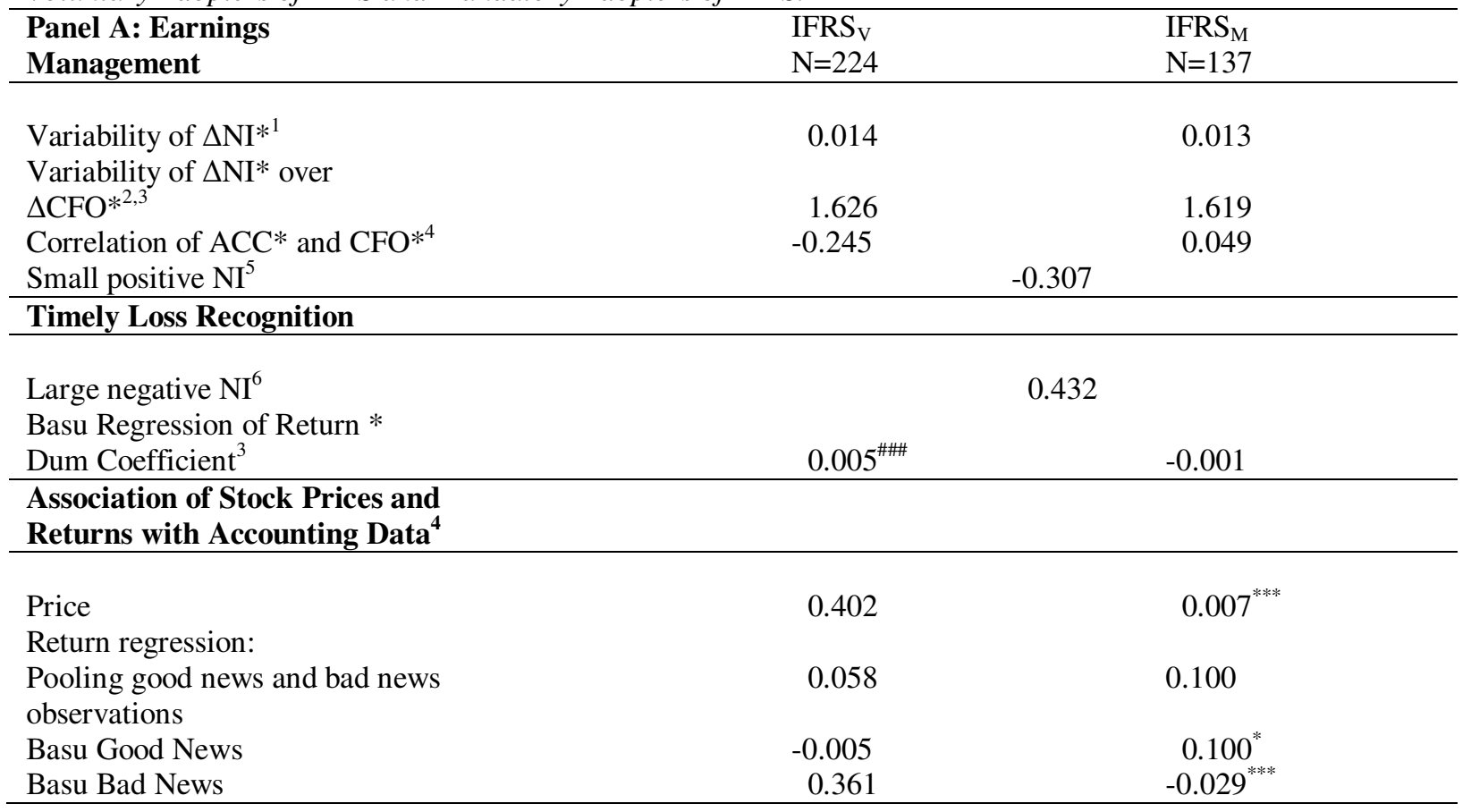

${ }^{*},{ }^{* *},{ }^{* * *}$ Significantly different between each category at the $0.01,0.05$, and the 0.10 respectively (two-tailed)

\#, \#, \#\#\# Significantly different from zero at the $0.01,0.05$, and the 0.10 respectively (two-tailed)

${ }^{1} \Delta \mathrm{NI} *$ is the variance of residuals from a regression of the $\Delta \mathrm{NI}$ on the control variables.

${ }^{2} \Delta \mathrm{CFO} *$ is the variance of residuals from a regression of the $\Delta \mathrm{NI}$ on the control variables.

${ }^{3}$ Variability of $\Delta \mathrm{NI} *$ over $\Delta \mathrm{CFO} *$ is the ratio of $\Delta \mathrm{NI} *$ divided by $\triangle \mathrm{CFO} *$.

${ }^{4}$ Correlation of $\mathrm{ACC}^{*}$ and $\mathrm{CFO} *$ is the partial Spearman correlation between the residuals from the ACC and $\mathrm{CFO}$ regression.

${ }^{5}$ SPOS is a dummy variable taking on the value 1 for observations for which the annual earnings scaled by total assets is between 0 and 0.01 , and 0 otherwise.

${ }^{6} \mathrm{Lneg}$ is a dummy variable taking on the value 1 for observations for which the annual earnings scaled by total assets is less than -0.20 , and 0 otherwise.

${ }^{7}$ The regression is $E P S=\beta_{0}+\beta_{1} R+\beta_{2} D U M+\beta_{3} R * D U M+\varepsilon$ where EPS is annual earnings per share deflated by share price at the beginning of the period, $R$ is annual return, and $D U M$ takes on the value 1 if the return is negative and 0 otherwise.

${ }^{8}$ The regression is $P=\beta_{0}+\beta_{1} E P S+\beta_{2} B V P S+\varepsilon$ where $P$ is price as of three months after the fiscal year end, EPS is earnings per share and $B V P S$ is the book value of shareholders' equity per share. All variables are scaled by share price six months after the preceding year-end.

${ }^{9}$ The Basu good and bad news regression is $E P S=\beta_{0}+\beta_{1} R+\varepsilon$, where EPS is earnings per share deflated by price at the beginning of the year and $R$ is the annual return. Good news observations are those for which $R$ is positive and bad news are those for which return is negative. We winsorize all continuous variables at the $1 \%$ level to control for outliers. 
Table 9: Analysis of Accounting Quality Using Observations from the 2005-2006 Period, Comparing Voluntary Adopters of IFRS and Adopters of IFRS Who Previously Reported Under US GAAP.

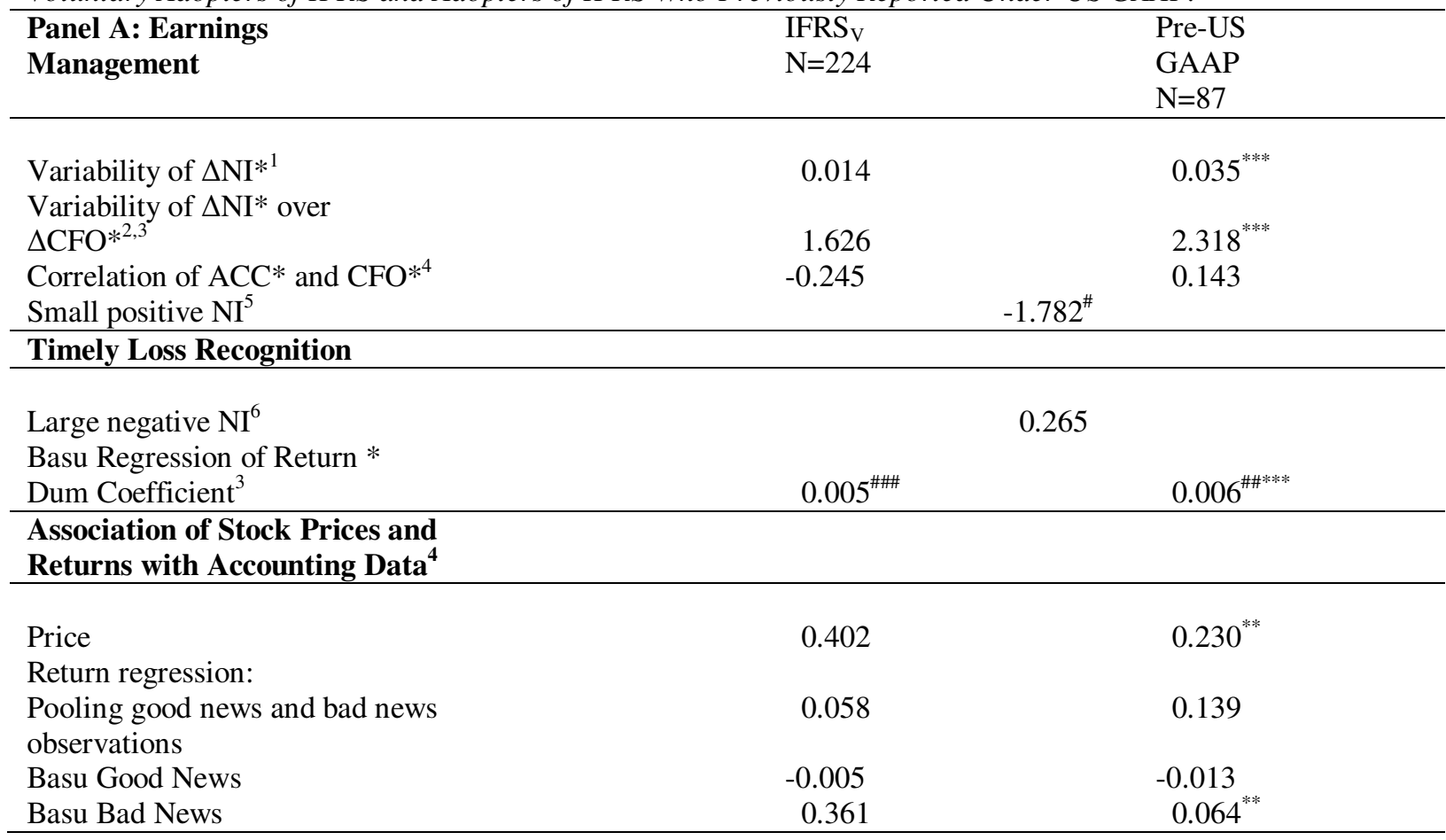

${ }^{*}, * *, * * *$ Significantly different between each category at the $0.01,0.05$, and the 0.10 respectively (two-tailed)

\#, \#, \#\#\# Significantly different from zero at the $0.01,0.05$, and the 0.10 respectively (two-tailed)

${ }^{1} \Delta \mathrm{NI} *$ is the variance of residuals from a regression of the $\Delta \mathrm{NI}$ on the control variables.

${ }^{2} \triangle \mathrm{CFO} *$ is the variance of residuals from a regression of the $\Delta \mathrm{NI}$ on the control variables.

${ }^{3}$ Variability of $\Delta \mathrm{NI}^{*}$ over $\Delta \mathrm{CFO} *$ is the ratio of $\Delta \mathrm{NI}^{*}$ divided by $\triangle \mathrm{CFO} *$.

${ }^{4}$ Correlation of ACC* and CFO* is the partial Spearman correlation between the residuals from the ACC and $\mathrm{CFO}$ regression.

${ }^{5}$ SPOS is a dummy variable taking on the value 1 for observations for which the annual earnings scaled by total assets is between 0 and 0.01 , and 0 otherwise.

${ }^{6}$ Lneg is a dummy variable taking on the value 1 for observations for which the annual earnings scaled by total assets is less than -0.20 , and 0 otherwise.

${ }^{7}$ The regression is $E P S=\beta_{0}+\beta_{1} R+\beta_{2} D U M+\beta_{3} R * D U M+\varepsilon$ where $E P S$ is annual earnings per share deflated by share price at the beginning of the period, $R$ is annual return, and $D U M$ takes on the value 1 if the return is negative and 0 otherwise.

${ }^{8}$ The regression is $P=\beta_{0}+\beta_{1} E P S+\beta_{2} B V P S+\varepsilon$ where $P$ is price as of three months after the fiscal year end, EPS is earnings per share and $B V P S$ is the book value of shareholders' equity per share. All variables are scaled by share price six months after the preceding year-end.

${ }^{9}$ The Basu good and bad news regression is $E P S=\beta_{0}+\beta_{1} R+\varepsilon$, where EPS is earnings per share deflated by price at the beginning of the year and $R$ is the annual return. Good news observations are those for which $R$ is positive and bad news are those for which return is negative. We winsorize all continuous variables at the $1 \%$ level to control for outliers. 